\title{
Vagyoneladás és a tulajdonosi struktúra változása az európai energiaszolgáltató szektorban 2010 és 2016 között
}

\begin{abstract}
Az elmúlt években az európai energiaszolgáltató szektorban zajló változások közül egyre nagyobb jelentőségüvé vált a vállalati vagyon értékesítése. Az eladott vagyonelemek köre igen széles volt, érintette az erőmüvi kapacitásokat, a villamosenergia-hálózatokat, a földgáz-infrastruktúrát, valamint teljes regionális vállalatcsoportokra is kiterjedt. Az energiaszolgáltatók által összeállított, általában több éven át tartó vagyonértékesítési programok megfogalmazott célja a vállalati eladósodottság mérséklése volt. A tulajdon újraelosztása során megváltoztak a vállalati méretek, átalakult az üzleti profil. A tulajdonosi viszonyok a villamosenergia- és földgázvagyon szinte minden szegmensében módosultak: növekedett a pénzügyi befektetők súlya, Európán kívüli, új befektetők is megjelentek. Mivel a tradicionális energiaszolgáltatók számára kedvezőtlen piaci feltételek tartósak, a vagyonértékesítési folyamat korántsem tekinthető lezártnak.

Journal of Economic Literature (JEL) kód: L94.
\end{abstract}

\section{A vállalati vagyon értékesítését kiváltó tényezők}

Az európai energiaszolgáltató szektor 1998 és 2007 között rendkívül dinamikusan fejlödött, a gazdasági növekedés indukálta villamosenergia-kereslet és a villamos energia piaci ára több éven keresztül növekedett. ${ }^{1}$ A 2008-as gazdasági és pénzügyi válság akkor következett be, amikor az ágazat még a beruházási ciklus felívelö szakaszában volt: sok, nagy kapacitású - elsősorban hagyományos - hőerőmüvet adtak át akkoriban, vagy állt közvetlenül befejezés előtt. Az energetikai beruházások finanszírozása a megvalósulás hosszú átfutási ideje és lassú megtérülése miatt hagyományosan elsősorban bankhitelekből történik. Ebben az évtizedben a banki források is bőségesen rendelkezésre álltak, és az energiaszolgáltatók évtizedeken keresztül a bankok kedvenc ügyfelei közé tartoztak. Ezt a szektor stabil és jól elörejelezhetö

\footnotetext{
${ }^{1}$ Az európai villamosenergia-piac átalakulásának okait és összefüggéseit csak annyiban érintjük, amennyiben a cikk témáját, az energiaszolgáltató szektor tulajdonviszonyainak változását magyarázza.
}

Székffy Klára az EVN AG (Ausztria) elemzője.

A kézirat első változata 2017. február 22-én érkezett szerkesztőségünkbe.

DOI: http://dx.doi.org/10.18414/KSZ.2017.7-8.774 
nyereségessége és a gazdaság ingadozásokkal szembeni viszonylagos állóképessége indokolta. A nemzetközi hitelminősítő intézetek rendszeresen vizsgálták a vállalatok hitelfelvevő képességének alakulását, és az energiaszolgáltatókat, valamint a szektor egészét a kis kockázatú, legjobb adós kategóriába sorolták. ${ }^{2}$ Az évtized végére a szektor hitelállománya kiugróan magas volt, a legtöbb energiaszolgáltatót a kapacitások üzembe lépését követően jelentős hiteltörlesztési kötelezettség terhelte.

A 2008-at követő közel egy évtizedben a hagyományos európai energiaszolgáltatók nyereségessége radikálisan és tartósan romlott. A gazdasági környezet romlását a villamos energia nagykereskedelmi árának alakulása érzékletesen szemlélteti (1. ábra).

\section{1. ábra}

A villamos energia nagykereskedelmi árának alakulása az európai piacokon, 2008-2016 Euró/megawattóra

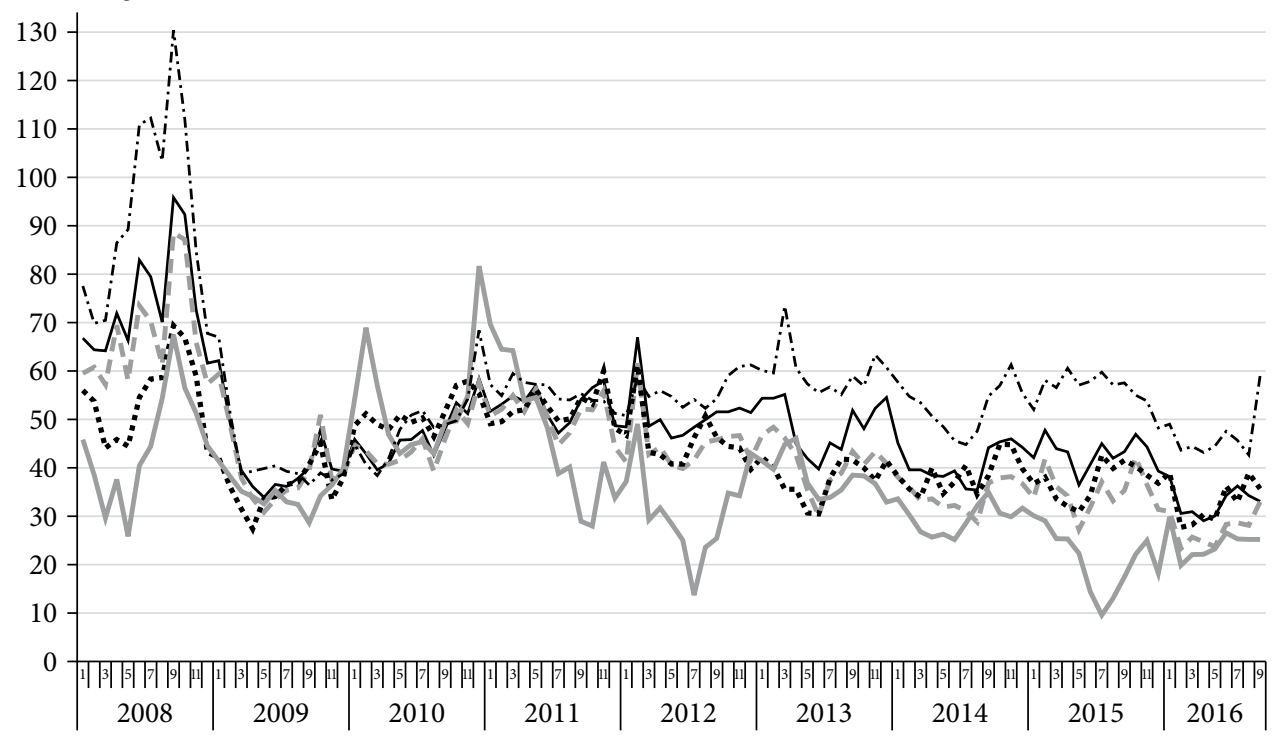

— Európai átlag - Platts PEP Index Észak-Európa

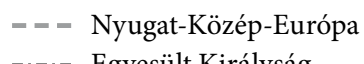

Kelet-Közép-Európa

Forrás: EC [2016] 15. o. 1. ábra.

Az energia, ezen belül is a villamos energia iránti kereslet a 2008-as gazdasági visszaesés hatására mérséklödött, a villamos energia ára 2009-ben az előző évhez viszonyítva közel felére esett vissza, majd 2011 végéig a gazdasági élénkülés hatására mérsékelten emelkedett. A dekonjunktúrát követően azonban sem a kereslet, sem az ár nem zárkózott fel a válság előtti szintre. Ennek egyik oka, hogy a 2010-es évek második felében elterjedtek azok a technológiák, a melyek az

${ }^{2}$ 2008-ban a Standard \& Poor's és a Moody’s hitelminősítők az energiaszolgáltató szektor vállalatait a legjobb $A A$ és $A 2$ kategóriába sorolták. 2016 végére azonban a legtöbb vállalat minősítése $B B B+$ és Baa1 szintre romlott. A nagy európai energiaszolgáltatók közül csak a francia EdF és Engie, valamint a német EnBW maradt továbbra is a legjobb adós kategóriában. 
energiafelhasználás hatékonyságának javulását segítették elő. Ennek következtében a gazdasági növekedés és az energiakereslet közötti, addig meglévő, rendkívül szoros kapcsolat gyengült.

Mint az 1. ábra mutatja, 2012-től az európai villamosenergia-piacokon az árak ismét drámaian csökkentek: a 2016-os átlagár a 2008-as átlagárnak alig 45 százaléka volt. ${ }^{3} \mathrm{Az}$ e folya mat mögött álló gazdasági és politikai tényezők árakra gyakorolt közvetlen hatását több kutatás is igyekezett számszerüsíteni. ${ }^{4}$

\section{2. ábra}

A villamos energia árának alakulását magyarázó tényezők 2008 és 2015 között a német piacon Euró/MWh

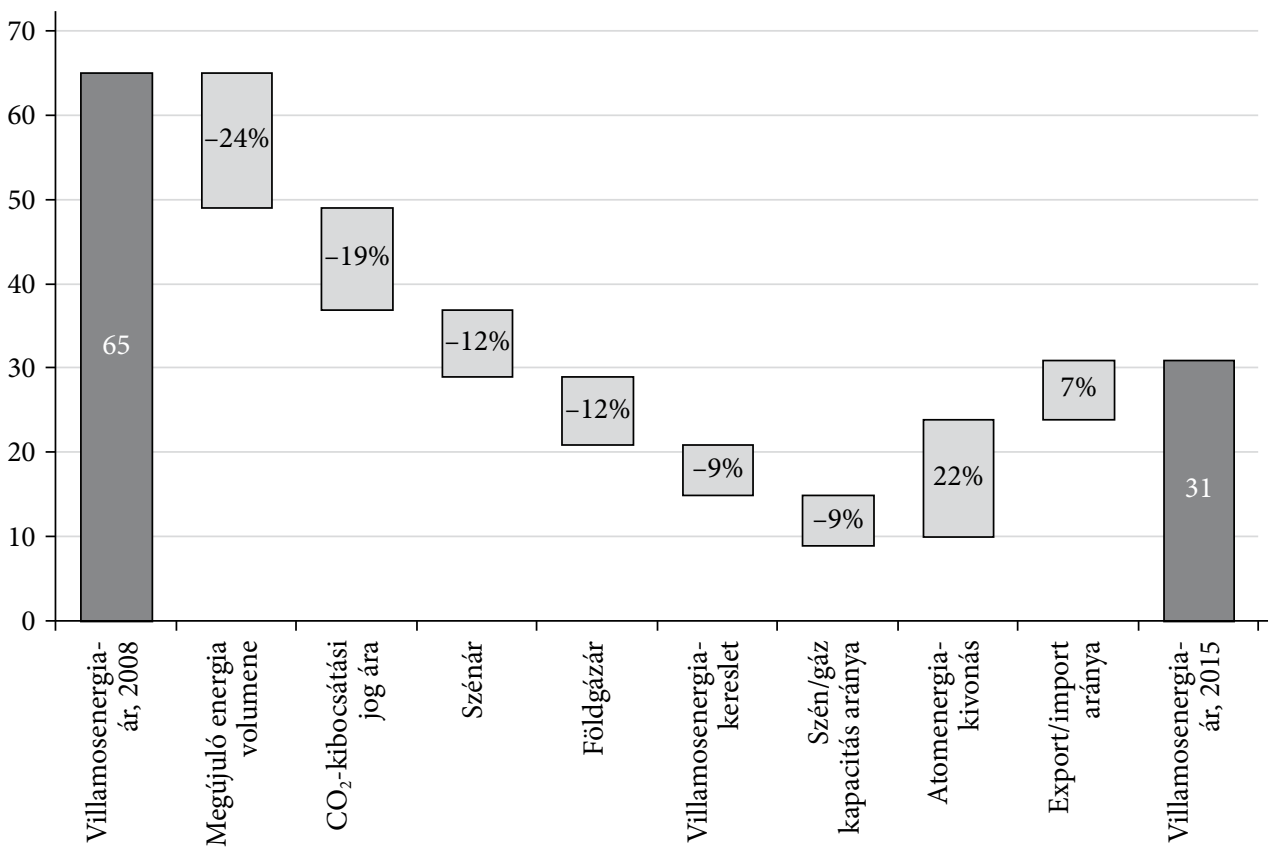

Megjegyzés: az ábrán az aznapi vagy 24 órán belüli szállítás esetén érvényes villamosenergiaárat magyarázó tényezők árra gyakorolt hatása a villamosenergia-ár százalékában szerepel. Forrás: Hirth [2018] online változata.

Hirth [2018] modellje a német piacon az áresést több alapvető tényezőre vezeti vissza (2. ábra), míg az atomenergia 2022-ig való teljes kivonására tett intézkedések és a tranzitlehetőségek szűkülése a villamos energia árát stabilizálta. A magyarázó tényezők között több külső tényező, politikai elhatározás is található, ezek a megújuló energia

${ }^{3}$ A villamos energia (zsinóráram) átlagára 2016-ban a német piacon 29 euró/megawattóra volt, szemben a 2008-as 65 euró/megawattóra értékekkel.

${ }^{4}$ A következőkben Hirth 2016-ban készített, de már online elérhető publikációját idézzük, a szerző a német piacon a villamos energia árának alakulását befolyásoló okokat igen részletesen vizsgálta, és nyolc alapvető tényezőt különített el. Más ex post modellek kevesebb háttérfaktorral dolgoznak (Everts és szerzőtársai [2016] és Kallabis és szerzőtársai [2016]). 
fejlesztésére, az atomenergia kivonására és a szén-dioxid-kibocsátási jog kereskedelmére, illetve mennyiségére vonatkozó döntések.

A modellek mindegyike a zöldenergia mennyiségi növekedését tartja a villamos energia árának alakulására ható legfontosabb tényezőnek, és csak ezt követi a széndioxid-kibocsátás szigorodó jogszabályozásából, a fütőanyagok (szén és földgáz) árának csökkenéséből, valamint a villamos energia iránti kereslet mérséklődéséből következő árhatás.

A fukusimai atomerőmüben 2011-ben bekövetkezett baleset Európában is az atomenergia-termelés biztonságával kapcsolatos félelmek felerösödéséhez vezetett. Ezt követően került a zöldenergia az európai energiapolitika középpontjába. A megújuló energiatermelés uniós és tagállami szintü ösztönzési rendszere rendkívül gyorsan kiépült, jelentős mértékben nőtt a zöldenergiát hasznosító villamosenergia-termelés pénzügyi támogatása. Ezt egészítette ki az a közvetlen hatósági beavatkozás, amely a zöldenergiának - szemben a hagyományosan megtermelt villamos energiával - az energiarendszerbe való belépésekor elsőbbséget biztosított.

Ezek a szabályozási elemek torzították az energiaszolgáltató szektor piaci viszonyait, és a tradicionális energiaszolgáltatók a megtermelt villamos energiát csak drasztikusan csökkenő árakon tudták értékesíteni. A villamosenergia-szektor piaci feltételeinek rosszabbodásával az előző évtized növekedési kilátásaira alapozott új erőművi kapacitások sem tudták elérni azt a jövedelmezőséget, amivel a beruházási döntések meghozatalakor kalkuláltak, így a felvett beruházási hitelek törlesztése a vállalatoknak egyre nagyobb terhet jelentett.

Az energiaszolgáltatók az eredményesség romlására kezdetben a hatásukat rövid távon kifejtő intézkedésekkel, a gazdaságtalanná vált erőművi kapacitások átmeneti vagy végleges leállításával, a termelési költségek és a folyó beruházások volumenének csökkentésével, a szükséges beruházások időbeli elhalasztásával reagáltak. Az így elért eredményjavulás azonban közel sem tudta a folyamatosan romló gazdasági környezet hatását ellensúlyozni. Ezért az energiaszolgáltatók egyre inkább a hosszú távú stratégiájuk újragondolására és átalakitására kényszerültek. Ennek megfelelően módosították beruházási terveiket, változtatták termelökapacitásaik összetételét, gyakran az egész vállalati struktúrát is átalakították. Beruházási hiteleiket pedig egyre inkább vagyontárgyaik eladásából származó bevételekkel igyekeztek törleszteni. A tulajdonosi szerkezet átalakulásához vezető vagyoneladás vagy vállalatfelvásárlás nem volt új jelenség az energiaszolgáltató szektorban, ennek minősége és iránya azonban 2010 és 2016 között alapvetően különbözött az előző évtizedekhez képest.

\section{Az európai energiaszolgáltató szektor szerkezetének átalakulása 1998 és 2009 között}

1998 és 2009 között az európai energiaszolgáltató szektorban jelentős volumenü, részben a nemzeti piacokon, részben határokon átívelö vállalatfelvásárlási, fúziós hullám zajlott le. E folyamat jogi, szabályozási feltételeit a szektor liberalizációját célzó intézkedések teremtették meg: az Európai Unió első liberalizációs csomagjának 
rendelkezéseit a tagországoknak a villamosenergia-ágazatban 1998-ig, a földgázszektorban pedig 2000-ig kellett bevezetniük.

A statisztikai adatok szerint az első évek tagországon belüli vagyoni koncentrációs folyamatát 2002 után már egyre inkább a nemzetközi tranzakciók váltották fel. Az 1998 és 2009 közötti periódusban az uniós engedélyezési eljárásához kötött, országok közötti, közel 250 tranzakció átlagos értéke 1 és 4 milliárd euró között mozgott, a tíz legnagyobb vállalati összevonás összértéke pedig 200 milliárd eurót tett ki (Leveque-Monturus [2008], PWC [2010]).

E periódusban a legtöbb és egyben a legnagyobb fúziók Olaszországban, az Egyesült Királyságban és Németországban zajlottak le. Olaszországban és az Egyesült Királyságban az energiaszolgáltató szektor privatizációja, Németországban pedig a szektor regionális és kommunális szintű széttagoltsága és a szinergiák kiaknázásának igénye állt a vállalatfelvásárlási folyamat mögött. Abban, hogy egyegy nemzeti piac mennyire válhatott a nemzetközi akvizíciók terepévé, a szektor meglévő koncentrációján felül fontos szerepet játszott az egyes nemzetállamok piacvédő, a külföldi befektetőket kevésbé beengedő politikája is. Így például Franciaország és Belgium - a szektorban müködő erős nemzeti vállalatok megléte és az ezeket védő szabályozási, politikai környezet miatt - kevésbé volt érintett a nemzetközi fúziós hullám által.

Az európai energiaszolgáltató szektor konszolidációjának meghatározó vállalati szereplői a német szolgáltatók, az E.On ${ }^{5}$ és az RWE, a francia Électricité de France (EdF) és a Gaz de France Suez (GdF), valamint az olasz Enel voltak. Néhány jelentős, ekkor végrehajtott tranzakciójuk jól jellemzi az egész szektor átalakulásának folyamatát.

Az említett francia és német cégek fő szerepet játszottak a brit energiaszektor privatizálásában is: az EdF egy, a Londont és környékét ellátó villamosenergia- és földgázszolgáltató (London Energy), az E.On egy közép-angliai villamos energiát termelö és elosztó (PowerGen), az RWE pedig egy villamosenergia- és földgázportfólióval egyaránt rendelkező vállalat (Innogy) meghatározó tulajdoni hányadához jutott. A lényegében állami irányítású EdF olasz és belga (Edison és Electrabel) versenytársait vásárolta fel. Az E.On a nyugat-európainál nagyobb növekedési lehetőséget ígérő dél-európai (olasz és spanyol) regionális piacokhoz jutott. Az évtized legnagyobb értékủ vállalatfelvásárlását az olasz Enel hajtotta végre egy spanyol integrált szolgáltató (Endesa) 25 százalékos tulajdonjogának megszerzésével. A nagy energiaszolgáltatók több kisebb energiapiacot is felosztottak egymás között. Így vált például a svéd Vattenfall és a német RWE a holland energiapiac meghatározó szereplöjévé.

A kelet-európai energiaszolgáltató szektor privatizációja során is a német, a francia és az olasz energiaszolgáltatók voltak aktívak. ${ }^{6}$

\footnotetext{
${ }^{5}$ A német villamosenergia-piac belső szerkezetét átalakító nagy tranzakció 2000-ben történt, amikor két nagy regionális szolgáltató, a Veba és a Viag összevonása révén létrejött az E.On.

${ }^{6}$ A kelet-európai piacból az E.On szakította ki a legnagyobb részesedést cseh, szlovák, magyar, lengyel, bolgár, román villamosenergia- és földgázrészesedések megvásárlásával. Az EdF a lengyel és a magyar, a GdF a szlovák, a lengyel és a román piacon vált közvetlen tulajdonossá. A Vattenfall lengyel, az Enel szlovák, román, bolgár, az RWE pedig cseh és szlovák érdekeltségekhez jutott.
} 
A vizsgált tízéves periódusban a domináns vállalatok olyan tulajdoni részesedések megszerzésére törekedtek, amelyek irányítói jogosítványokat biztosítottak, és így az átvett vállalatokat szorosan beépíthették cégbirodalmukba.

\section{Vagyoneladási programok az energiaszektorban 2010 és 2016 között}

A villamos energia piaci árának 2008 utáni drasztikus csökkenése legérzékenyebben a jelentős erőművi kapacitású, vertikálisan felépített energiaszolgáltatókat érintette. Ezen szolgáltatók mindegyike fontos pénzügyi stabilizáló eszköznek tekintette a vagyoneladást, a megcélzott árbevételt és a lebonyolítás határidejét is rögzítő értékesítési programot dolgozott ki. Mivel a szektorban nem egyszeri negatív változás történt, hanem a gazdasági feltételek romlása tartós volt, az értékesítésre kiválasztott termelöeszközök is folyamatosan veszítettek az értékükből. Azért, hogy a tervezett bevételt elérjék, a szolgáltatók többször is módosították kezdeti vagyoneladási terveiket, újabb vagyoni elemekkel bővítették ezek listáját, vagy egy-egy program lezárását követően új eladási listát állítottak össze.

A vagyontárgyak eladásából származó bevételek segítették a vállalatok pénzügyi helyzetének rövid távú stabilizálását, és részben fedezték az előző periódusban felvett beruházási hitelek törlesztését. A gazdasági feltételek tartós romlása miatt a hitelminősítés megőrzése egyre inkább a vállalatok kiemelt céljává vált, a vagyoneladási programok léte és sikeressége pedig a vállalati hitelminősítésben az értékelési rendszer egyik új elemévé vált. A vizsgált periódus kezdetén különösen fontos volt a hitelfelvételi képesség megörzése és a hitelek után fizetendő kamatok szintjének stabilizálása: 2010 körül ugyanis az energiaszolgáltatók átlagosan évi 5 százalékos vagy ezt még némileg meg is haladó éves kamatot fizettek a beruházási hitelek után. ${ }^{7}$

Az elemzésbe azok a vállalatok kerültek be, ahol egy vagy több, a vállalatok likviditási helyzetének stabilitását, a korábban felvett beruházási hitelek törlesztését lehetővé tevő vagyonértékesítési programot hirdettek meg. Ezek közé tartozik a finn Fortum, a svéd Vattenfall, a három nagy német szolgáltató, az E.On, az RWE és az Energie Baden-Württemberg (EnBW), a két francia vállalatcsoport, az EdF és az Engie (2015 előtt GdF), az olasz Enel, a spanyol Iberdrola és a Gas Natural, valamint a portugál Energias de Portugal (EdP).

A vállalatok mindegyike az európai energiaszektor meghatározó integrált, azaz az energiapiac minden szegmensében jelen lévő, a villamos energia termelésének/elosztásának/kereskedelmének, valamint a földgáz szállításának/elosztásának/értékesítésének a feladatait ellátó energiaszolgáltatók. A vállalatok egy másik csoportja - a

\footnotetext{
${ }^{7}$ A szolgáltatók törekedtek kamatterheik optimalizálására is. Átalakították hitelállományuk struktúráját, növelték a fix kamatozású és az euróhiteleik arányát, valamint a vállalati kötvényeknél olcsóbb, részvényekre átváltható kötvényeket bocsátottak ki. A vizsgált években terheiket mérsékelte a hitelkamatok általános csökkentése is. Mindezek hatására 2015-2016-ra az energiaszolgáltatók által fizetendő átlagos kamat már csak az évi 2,0-3,5 százalékos sávban mozgott.
} 
magasfeszültségü villamosenergia-hálózatot működtető vagy a földgáz nemzetközi tranzitját lebonyolító, úgynevezett átviteli rendszerirányítók (Transmission System Operator, TSO), az elosztóhálózati rendszerek üzemeltetöi (Distribution System Operator, DSO), illetve a kizárólag zöldenergiát hasznosító villamosenergia-termelők szabályozott piaci környezetben müködnek, így eredményességük 2010 után relatíve stabil maradt. Ezek a vállalatok is értékesítettek néhány vagyoni elemet, ez a tevékenység azonban megmaradt a hagyományos portfóliótisztítás körében, az értékesítésből származó bevételeket pedig magasabb hozamot ígérő, új kapacitások megvásárlására vagy kiépítésére fordították.

Az elemzésbe bevont vállalatok vagyonértékesítési programjainak nagysága és idöbeli megvalósítása eltérő volt. A három német (E.On, EnBW és RWE) és két skandináv (Fortum és Vattenfall) szolgáltató állította össze leggyorsabban az eladásra kiválasztott vagyoni elemek listáját, és e programok árbevételi célját is igen magasan állapították meg. Ennek oka, hogy a zöldenergia támogatási rendszere a német és az észak-európai energiapiacokat rendkívül radikálisan átalakította, és ez az integrált vállalatok gazdasági helyzetének gyors romlásához vezetett. ${ }^{8}$ Ez a szolgáltatói kör 2016 közepéig már közel 100 százalékban teljesítette is vagyoneladási programját.

Az európai energiaszolgáltatók közül a nominális értékben legjobban eladósodott olasz Enel és két nagy francia energiaszolgáltató, az EdF és az Engie, vagyoneladási programjait később jelentették be, $s$ az árbevételi céljaik is szerényebbek voltak. A német és a skandináv integrált áramszolgáltatókkal szembeni késést részben a villamos energia nagykereskedelmi árának regionális eltérése indokolja. A déleurópai energiaszolgáltató piacok relatíve elzártak, a termelőkapacitások összetétele miatt a villamos energia átlagos árszínvonala meghaladja a többi európai régióra jellemző árszintet. Ezeken a piacokon a villamos energia árának csökkenése és így a vállalati nyereségromlás mérsékeltebb volt.

A tervek és a megvalósítás eltérésének a gazdálkodási feltételek romlásán túlmutató oka a szolgáltatók tulajdonosi hátterének különbözősége is volt. A két német vállalat, az E.On és az RWE döntően, a finn Fortum pedig részben magán- és intézményi befektetők tulajdonában van. A svéd Vattenfall állami vállalat, a francia és az olasz szolgáltatóknál pedig továbbra is jelentôs az állam tulajdoni részesedése. Az állam mint tulajdonos az elmúlt években a pénzügyi és magánbefektetőknél könynyebben viselte el az energiaszektorból származó vállalati osztalékok stagnálását (esetleges csökkenését), s az üzleti stratégia újrafogalmazására is hosszabb időt fordított. ${ }^{9}$ E vállalatok megítélésekor a hitelminősítők is figyelembe vették az egyedi

\footnotetext{
${ }^{8}$ A svéd Vattenfall a német energiapiac negyedik legnagyobb szereplöje volt, így e piac negatív irányú változása is nagymértékben rontotta a svéd vállalatcsoport jövedelmezőségét.

${ }^{9}$ A francia állam részesedése az EdF-ben és az Engie-ben 85,6 százalék és 28,7 százalék. A Fortumban 50 százalékos a finn állam részesedése. Az olasz állam 23,6 százalékban tulajdonolja az Enelt. A német energiapiac harmadik legnagyobb szereplője, az EnBW a többi német szolgáltatóval egy időben állította össze vagyoneladási programját, ennek végrehajtási határidejét azonban időközben 2020-ig meghosszabbították. Ennek a fö oka az, hogy az EnBW 97 százalékban a baden-württembergi tartományi kormány tulajdonában áll. A tulajdonos lecserélte ugyan a vállalati vezetést, és új vállalati stratégiát alakíttatott ki, a vagyoneladási program végrehajtását azonban a kedvezőtlen energiapiaci körülmények között nem siettette.
} 
tulajdonosi hátteret: az állam vagy a regionális kormányzatok pénzügyi stabilitása pozitív tényezőként került elismerésre a vállalati hitelminősítésben. A szektor gazdasági feltételeinek tartós romlása azonban ezeket a szolgáltatókat is rákényszerítette az eladásra szánt vagyoni kör bővítésére, a célösszeg emelésére, gyakran pedig a teljesítés végső határidejének meghosszabbítására.

A szektorban 2010 és 2016 között értékesített vagyontárgyak teljes összegéről nincs információnk. Ezt sem a nagyszámú szereplői kör, sem a gyakran üzleti titokként kezelt értékesítési árak nem teszik lehetővé.

A vagyonértékesítési programmal rendelkező tizenegy szolgáltató által nyilvánosságra hozott árbevételek alapján 2010 és 2016 között több mint 90 milliárd euró vagyon cserélt gazdát (3. ábra). ${ }^{10}$ A vagyonelemek eladásának valódi jelentőségét mutatja az árbevételeknek az állóeszközök összértékéhez viszonyított aránya (4. ábra). ${ }^{11}$

\section{3. ábra}

Az európai energiaszolgáltatók vagyoneladási programjainak értéke 2010 és 2016 között (milliárd euró) $)^{*}$

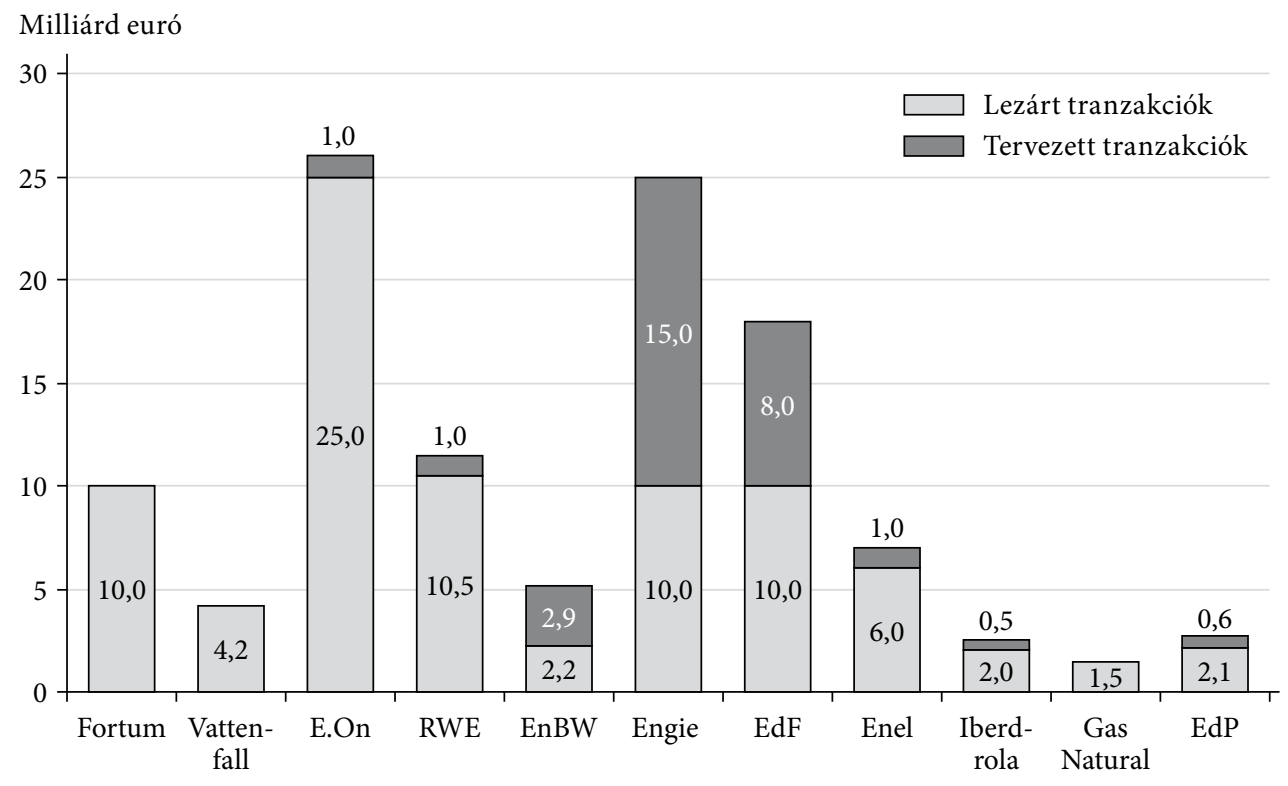

* Az ábra a 2016 végéig megkötött vállalati vagyoneladásokat tartalmazza.

Forrás: a vállalatok 2010-es és 2016-os évekről készített konszolidált éves beszámolói, illetve stratégiai prezentációi.

${ }^{10}$ A vállalatok a vizsgált időszakban állóeszközeik (termelőkapacitások, részesedések) értékét a negatív jövedelmi kilátások alapján a terv szerinti értékcsökkenésen felül összesen több mint 100 milliárd euróval csökkentették. Ez a költségelem nem tükröződik a vállalatok pénzmozgásában, azonban csökkenti az éves nyereséget.

${ }^{11}$ Az elemzésben 2010-et tekintjük a vagyoneladási folyamat kezdeti évének. A 4. ábrán az árbevételeket az energiaszolgáltatóknak a 2010. év végén a konszolidált éves beszámolóiban feltüntetett összes állóeszközértékéhez viszonyítottuk. 
4. ábra

A vagyoneladásból származó árbevételek állóeszköz-állományhoz viszonyított aránya 2010 és 2016 között (százalék)

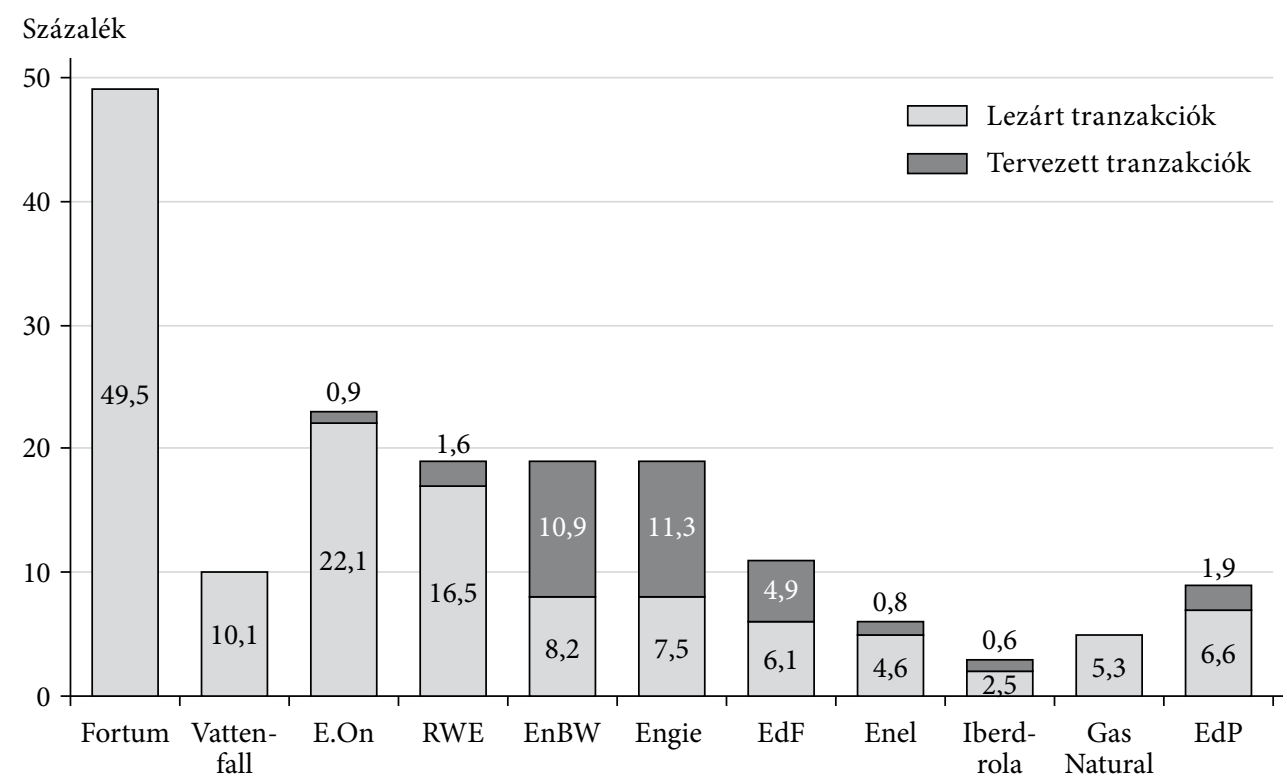

Forrás: a vállalatok 2010-es és 2016-os évekről készített konszolidált éves beszámolói.

A vállalatok átlagosan állóeszközvagyonuk 10-20 százalékát értékesítették, illetve e vagyonrész értékesítését tervezik 2020 -ig. A legnagyobb arányt itt is a német szolgáltatók, E.On, RWE, EnBW, valamint a francia Engie képviseli.

Az állóeszköz-állomány értékéhez viszonyítva az átlagot jóval meghaladó arányú volt a Fortum vagyoneladása. A finn szolgáltató egyedülálló stratégiát követett azzal, hogy eladta a stabil jövedelmet biztosító összes hazai és nemzetközi magasfeszültségủ villamosenergia-hálózatát, illetve az e hálózatokban meglévő érdekeltségeit. Ezzel a vállalat mérete, stabilitása és jövedelemtermelő képessége radikálisan megváltozott. A cég a vagyoneladásból származó, számottevő árbevételt a következő években kívánja befektetni. Stratégiai célja az energiaszektor új - okos (smart) - technológiát alkalmazó szegmensében való növekedés, és az e technológiára szakosodott vállalkozások megvásárlása.

A két spanyol energiaszolgáltató - az Iberdrola és a Gas Natural - összeállított ugyan vagyonértékesítési programot, ezek azonban kisebb jelentőségűek voltak, a regionális részesedések csökkentését és az üzleti portfólió tisztítását szolgálták.

Mivel az energiaszolgáltatók vagyoneladási programjuk céljaként magas eladósodottságuk csökkentését jelölték meg, érdemes megnézni, hogyan változott ez a mutató 2016-ra a kiinduló évhez, 2010-hez képest (5. ábra).

A vállalatok a vagyon értékesítéséből származó bevételeknek csupán egy részét fordították a beruházási hitelek visszafizetésére. A nettó adósság csökkenése így jóval kisebb volt, mint az eladások összértéke. Kivételt jelent a finn Fortum, amely 
5. ábra

A vállalati eladósodás (nettó adósságállomány) 2010 és 2016 közötti alakulása (milliárd euró)* Milliárd euró

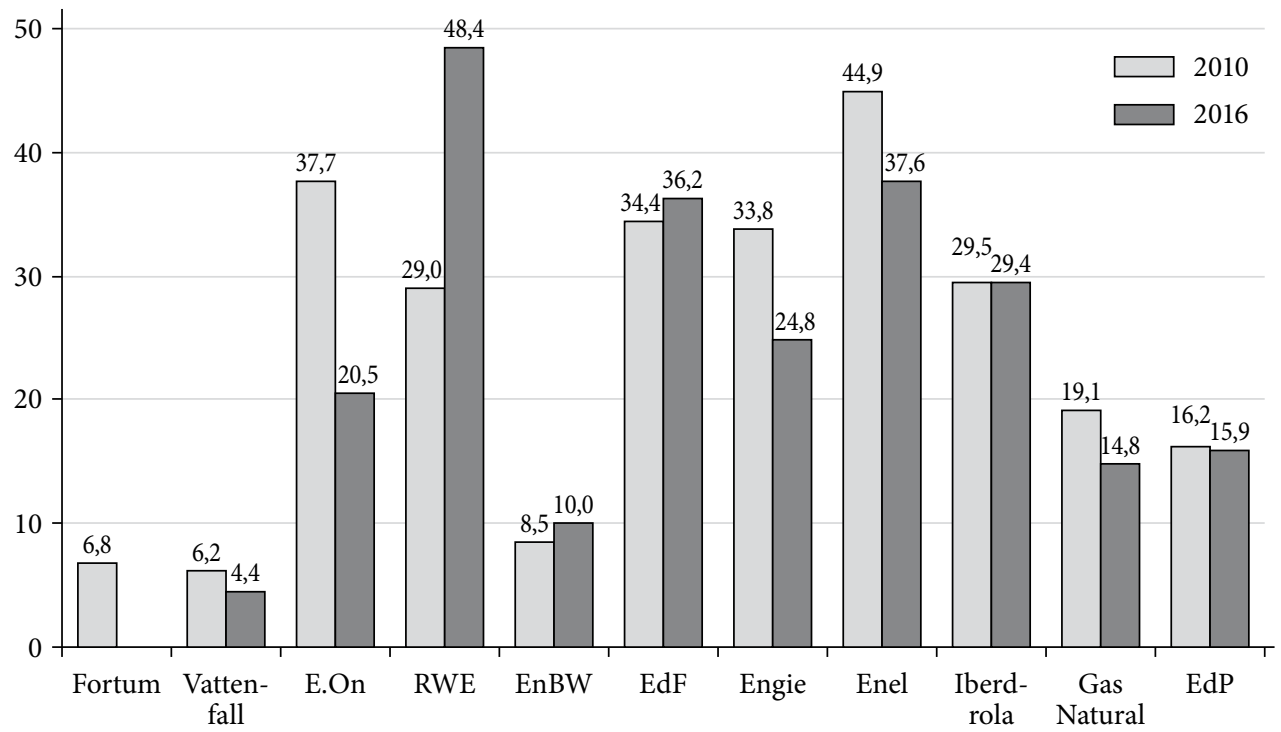

* Az E.On és az RWE 2016-os adata az anyavállalat és az ebben az évben leválasztott leányvállalatok együttes nettó adósságállományát tartalmazza.

Forrás: a vállalatok 2010-es és 2016-os évekről készített konszolidált éves beszámolói.

az eladott vállalati vagyonból nemcsak leépítette teljes hitelállományát, hanem jelentős, szabadon felhasználható pénztőkével rendelkezett 2016 végén.

Három vállalat - az RWE, az EnBW és az EdF - nettó adósságállománya 2016-ra még növekedett is. Ezt az eltérést a szektor gazdasági feltételeinek általános romlásán kívül más tényezők is magyarázzák. Az elmúlt években az atomerőművi kapacitásokkal kapcsolatos kiadások emelkedése számottevően növelte az atomenergiaszolgáltatók kiadásait és jövőbeli kötelezettségeit. E pénzügyi terhek közé nemcsak a bezárásra ítélt atomerőmüvek bontással kapcsolatos kiadásai és az atomhulladék tárolásának finanszírozása tartozik, hanem az atomerőművi biztonságtechnika 2011 után megnövekedett beruházási-modernizálási költségei is. ${ }^{12}$

Az eladósodottsági szintet rövid távon a vállalati létszámleépítéshez kapcsolódó terhek is negatívan érintették. A kamatok éveken át tartó csökkenése növelte a tartalékalapokkal - így a vállalati nyugdíjalapokkal - kapcsolatos kötelezettségeket is. $S$ végül: a folyó és tervezett beruházásokat a szolgáltatók az elmúlt években csökkentették ugyan, ezek finanszírozására azonban romló eredményeik miatt gyakran újabb banki forrásokat vettek igénybe.

\footnotetext{
${ }^{12}$ Ez az elemzésben szereplő energiaszolgáltatók szinte mindegyikét érinti. A németországi atomerőművi kapacitásokkal rendelkező vállalatok - E.On, RWE, EnBW, Vattenfall - bezárással kapcsolatos kötelezettségei nőttek a legjobban. Más vállalatok - így az EdF, az Engie, a Fortum és a Vattenfall (svéd atomerőművek), az Enel - terhei a működő atomkapacitások növekvő biztonságtechnológiai követelményei és az új beruházások emelkedő költségei miatt növekedtek.
} 


\section{Az energiaszektorban 2010 és 2016 között értékesített vagyonelemek típusai}

A vagyonértékesítési programokba bevont eszközök összetételének alakulása azt mutatja, hogy a vállalat az ágazat válságának kezdeti szakaszában (2010 és 2013 között) még a kisebb jelentőségünek ítélt, jórészt partnerekkel közösen birtokolt kapacitásokat vagy a fötevékenységen kívüli vagyonelemeket kívánták értékesíteni. Később, 2014 és 2016 között azonban egyre értékesebb termelőkapacitásokat, részesedéseket, teljes tevékenységi köröket is bevontak. Ez a váltás már mindenütt az újrafogalmazott vállalati stratégiát tükrözte: a nemzetközi portfólió átalakítása során gyakran az alig néhány évvel korábban létrehozott regionális érdekeltségeket, integrált vállalatcsoportokat értékesítették.

E folyamat azt eredményezte, hogy az energiaszolgáltatók feladták hagyományos európai piacaik többségét, és a vállalati növekedés lehetőségeit ma már az európai kontinensen kívül, elsősorban Latin-Amerikában és Ázsiában keresik.

2010 és 2016 között az energiaszolgáltatók vagyontárgyaikat túlnyomórészt nyilvános pályázati kiírás útján, elsősorban a szakmai és az intézményi befektetők számára értékesítették. 2016-ban azonban sikeresen zárult le több, a magánbefektetőket is megcélzó, nyilvános, tőzsdei úton lebonyolított vállalateladás is.

\section{Erömüvi kapacitások}

A villamos energia nagykereskedelmi árának zuhanása következtében az alacsony nyereségességü vagy veszteséget termelő kapacitások zömét átmenetileg vagy véglegesen kivonták a termelésből. ${ }^{13}$ Ezek elsősorban a modern földgázalapú vagy a viszonylag új és nagyobb hatékonyságú széntüzelésü erőművek voltak. Az alacsony nyereségességü hőerőmüvek egy csoportját azonban sikeresen értékesítették.

A hagyományos hőerőmüvek értékesítésére elsősorban a sokszereplős energiapiacokon volt lehetőség. Ennek példájaként említhetjük a német energiapiacot, ahol a négy nagy szolgáltató mellett több mint 300 regionális termelővállalat és közel 1000 energiakereskedő működik. ${ }^{14}$ Itt a kisebb erőművi kapacitások tulajdonjogán hagyományosan a nagyvállalatok és a helyi szolgáltatók osztoztak. A kisebb partnerek helyi piaci pozícióik megerősítése érdekében szívesen vették át a domináns partnerek tulajdoni részesedését. A tulajdon ilyen típusú újraelosztása a szektor válságának kezdeti éveiben volt tipikus, mivel ekkor az ágazat visszaesését még átmenetinek, konjunkturális jellegünek ítélték meg.

\footnotetext{
${ }^{13}$ Németországban átmenetileg vagy véglegesen leállították a földgázüzemű erőművi kapacitások 30 százalékát. Ezek kétötöde tíz évnél fiatalabb volt. A feketeszén-bázisú erőművek 23 százaléka, a barnaszén-tüzelésű kapacitások 10 százaléka nem működik. A leállított erőművek nagy része a modern kapacitások közül került ki. Több földgáz- és szénbázisú kapacitás közvetlenül elkészülte után lett tartalék kapacitásnak nyilvánítva.

${ }^{14} \mathrm{Az}$ E.On, az RWE, az EnBW és a Vattenfall termelése hagyományosan a teljes német villamos energia iránti kereslet közel 80 százalékát fedezte.
} 
Az erőművi piacon idővel egyre nagyobb súlyt kapott a megújuló energiát hasznosító kapacitások értékesítése. E vagyonelemek közé a vízi erőmüvek és a hosszú távon garantált - a villamos energia mindenkori nagykereskedelmi árától független - átvételi árakkal támogatott szélerőmüvi parkok tartoztak.

Alacsony müködési költségeik, ritkaságértékük miatt a vízi erőművek az energiaszolgáltatók értékes megújulóenergia-forrásai. Az ágazati jövedelmezőség tartós romlásával azonban több jelentős vízi erőművet is eladtak. Néhány példa a tulajdoni átrendeződésre. Az olasz Enel és a finn Fortum több belföldi vízi erőmüben meglévő részesedését értékesítette korábbi tulajdonostársainak és infrastrukturális befektetésre specializálódott pénzügyi alapoknak. Az E.On a német vízi erőművi kapacitásának felét elcserélte egy török energiaportfólióra, majd az olasz piacról való teljes visszavonulása részeként az ottani vízierömü-kapacitásaitól is megvált.

A szélerömüvi parkok adásvétele az utóbbi néhány év új jelensége. E vagyon vonzerejét a hosszú távon garantált átvételi árak és az így kalkulálható, viszonylag stabil jövedelmezőség adja.

Az eddig lezárt tranzakciók mögött az eladók eltérő motivációi fedezhetők fel. A Fortum stratégiát váltott, és ezért több hazai szélerőművi tulajdonát értékesítette. A spanyol Iberdrola kivonult a lengyel energiapiacról, és szélerőművi parkját egy helyi energiavállalatnak adta el. A portugál EdP nemzetközi (olasz és lengyel) szélerőművi tulajdonának egy részét új kínai tulajdonosának értékesítette. A francia Engie pedig a kockázatcsökkentés és a beruházási költségek megosztása érdekében pénzügyi befektetőket vont be szélerőmüvi beruházásaiba.

A tengeri szélerőmüvi parkoknak nemcsak a beruházási költsége kiugróan magas, hanem maga az építés is több évig tartó, komplex feladat. Ezért a pénzügyi befektetők gyakran csak az üzembe helyezést követően vásárolnak tulajdonrészt e kapacitásokban. A német EnBW erre alapozza jelenlegi üzleti stratégiáját. A parkok létesítését még teljes egészében saját hatáskörben és finanszírozásban bonyolítja le, és csak ezt követően ad el kisebbségi részesedéseket pénzügyi befektetőknek vagy kisebb helyi kommunális szolgáltatóknak.

\section{Szénhidrogénvagyon és -részesedések}

A könnyen értékesíthető tulajdoni elemek közé tartozott az energiaszolgáltatók kőolaj- és földgázvagyona vagy a szénhidrogén-kitermelő cégekben meglévő közvetlen részesedése. $\mathrm{E}$ vagyontípus aránya azonban nem volt jelentős az energiaszolgáltatók üzleti portfóliójában, gyakran csak az energiahordozók áralakulásában rejlő kockázatok mérséklésének volt az egyik eszköze.

Néhány példa az orosz szénhidrogén-részesedések értékesítésére: a vizsgált periódusban az Enel vagyoneladásból származó bevételének döntő hányada egy szibériai földgázrészesedésének értékesítéséből származott, az E.On pedig egy kisebb Gazprom-befektetéstől vált meg. Mindkét tranzakciónál helyi partnerek vagy bank volt a vásárló fél. Az Enel röviddel korábban értékelte át orosz üzleti portfólióját, és meghirdette egy ottani szénbányája értékesítését. 
Több északi-tengeri kőolaj- és földgázbefektetés is eladásra került: az Engie értékesítette a brit partoknál található szénhidrogénmezőkben lévő részesedését. Ennél jóval jelentősebb tranzakciónak számított az RWE és az E.On portfóliótisztítása. A két német vállalat a norvég és a brit partoknál lévő szénhidrogénmezőket adta el ugyanannak az orosz magánbefektetőnek. Ezeket a tranzakciókat az érintett országok kormányai elözetesen engedélyezték.

Az elmúlt évben a Vattenfall portfóliójából kikerültek a német lignitbányák és az erre épülő erőművi kapacitások. Az előző példáktól eltérően azonban ez a tranzakció hatalmas, egyszeri veszteséggel járt, és az eladó továbbra is viseli a bányák rekultiválásának pénzügyi terheit. ${ }^{15}$

\section{Részesedések az európai földgáz-infrastruktúrában}

A nemzetközi földgáz-infrastruktúra részei - így a nagynyomású távvezetékek (TSO) és a kereskedőcégek - a földgáz energiaellátásban betöltött szerepe alapján az energiaszolgáltató szektor könnyen és kedvező áron értékesíthető vagyonelemei voltak.

A két nagy német szolgáltató vagyonértékesítési programjaiban fontos szerepet játszott az európai földgázszállításban és -kereskedelemben meglévő érdekeltségeik csökkentése, illetve teljes leépítése. Az E.On először hazai érdekeltségei egy részét értékesítette: eladta a földgáz-tranzithálózatban és több regionális elosztóhálózatban meglévő részesedését. Ezt követően felszámolta közép-európai piaci pozícióit, eladta a magyar földgáztárolókat és az ehhez kapcsolódó kereskedővállalatot, a szlovák földgáztárolókban és a szlovák és a cseh nagynyomású földgázvezetékben tulajdonolt részesedéseit, valamint a prágai távfütőhálózatot is. Ezenfelül az E.On az Európát és Nagy-Britanniát összekötő, tenger alatti földgázvezeték tulajdonosi csoportjából is kilépett. Összességében a vállalatcsoport 20 milliárd eurós vagyoneladási árbevételének közel fele származott a földgáz-infrastruktúra elemeinek értékesítéséből. Az RWE az orosz földgáztranzit lebonyolításáért felelős cseh vállalatban és a Fővárosi Gázmüvekben meglévő kisebbségi részesedéseit értékesítette.

A francia Engie is megvált több földgáz-infrastrukturális befektetésétől: eladta a belga földgáz-nagykereskedelmi vállalatban és cseppfolyóshidrogén-tárolóban, egy olasz földgázelosztó hálózatban lévő érdekeltségeit, csökkentette a holland, a dán és a német hálózatokat összekapcsoló földgázvezetékben meglévő tulajdoni hányadát. Az E.On-nal együtt vált meg a szlovák földgáz-nagykereskedelmi vállalatban tulajdonolt kisebbségi részesedésétől is.

A Fortum a nemzetközi földgázüzletben is új stratégiai irányokat jelölt ki. A hazai nagynyomású földgázvezetékben tulajdonolt részesedése a finn államhoz került, és így az ismét 100 százalékos állami vállalattá vált. ${ }^{16}$ A finn vállalatcsoport elhagyta a korábban stratégiai befektetésként kezelt észt földgázpiacot, és belépett a lengyel energiapiacra.

\footnotetext{
${ }^{15}$ A svéd kormány a Vattenfall tulajdonosaként Svédország teljes éves szén-dioxid-kibocsátásának csökkentése érdekében ösztönözte a vállalat német lignitportfóliójának minél gyorsabb eladását.

${ }^{16}$ A finn állam e tranzakciót megelőzően visszavásárolta a Gazprom e vállalatban (Gasum) birtokolt részesedését.
} 
2016-ban az orosz földgáz importjában és belföldi elosztásában is fontos szerepet betöltő német Thyssengas került egy holland befektetőből és a francia EdF-ből álló konzorciumhoz. ${ }^{17}$ Ez év végén egy francia állami bank az EdF-től magasfeszültségü távvezeték-hálózatának közel felét vásárolta meg. Ezt a tranzakciót az EdF finanszírozási szükségletei tették szükségessé. A portugál EdP építette le spanyol földgázbefektetéseit.

\section{Részesedések a villamosenergia- és földgázelosztó hálózatokban}

Az energia végső fogyasztókhoz való eljuttatására szolgáló villamosenergia- és földgázelosztó hálózatok (DSO) is az értéküket viszonylag stabilan megőrző vagyonelemek. A hálózatirendszer-üzemeltetők a piac szabályozott szegmensébe tartoznak: az energiafelügyeleti szervek, hatóságok 3-5 évre elöre rögzítik a szabályozási paramétereket.

Az elemzésbe bevont legtöbb energiaszolgáltató ennek ellenére leépítette a hálózati részesedéseit. Ebben a döntésben a rövid távú pénzügyi érdekeknek és az értékesítés során elérhető kedvező áraknak volt nagy szerepük. Új tulajdonossá pedig a tervezhető, egyenletes nyereség elérésében érdekelt pénzügyi befektetők, nyugdíjintézetek és -biztosítók váltak.

A hálózati vagyonelemek értékesítésében a Fortum igen radikális volt, eladta a teljes villamosenergia- és földgázelosztó hálózatát. Ezeket döntően nemzetközi és hazai befektetőkből álló alapok vásárolták meg. A Vattenfall is értékesítette a finn elosztóhálózatokban meglévő befektetéseit, és csökkentette német részesedéseit is. ${ }^{18} 2016$-ban az európai földgáztranzit egyik fontos szereplöje, az olasz Snam leválasztotta és sikeresen tőzsdére vitte a belföldi földgázelosztásban részt vevő leányvállalatát, az Italgast.

\section{Hálózathoz köthetö egyéb vagyonelemek}

Értékesítésre került az energiaszolgáltatók vízmüportfóliójának néhány eleme is. E tevékenység - mint minden hálózathoz kötött iparág - szabályozott piaci feltételek között müködik, így tervezhető nyereséget biztosít tulajdonosának. A vizsgált energiaszolgáltatóknál e tevékenység súlya nem volt számottevő, így az eladásokat elsősorban a portfóliótisztítás, és kevésbé az elérhető árbevétel nagysága motiválta. Néhány nagyobb vagyoneladás e körben: az Engie megvált a Bristol Waterben lévő többségi részesedésétől, az RWE a Thames Water Utilitytől és a Berliner Wassertől. Ezek a részesedések helyi kormányzatokhoz és pénzügyi befektetőkhöz kerültek.

\footnotetext{
${ }^{17}$ A Thyssengast egy infrastrukturális beruházásokra specializálódott ausztrál pénzügyi befektetési alap, a Macquarie vásárolta meg az RWE-től 2011-ben.

${ }^{18}$ Hamburg Vattenfall által tulajdonolt és müködtetett villamosenergia- és távfütőhálózata 2013-ban önkormányzati kezelésbe került, ugyanis a város lakóinak többsége megszavazta a hálózatok visszavásárlását. Ezt követően a német főváros lakosságát is megkérdezték a hálózatok működésével kapcsolatos véleményükről. A berliniek azonban továbbra is bizalmat szavaztak a svéd energiaszolgáltatónak.
} 


\section{Regionális energiavállalatok értékesitése}

Az egyedi vagyonelemek eladásán kívül gyakorivá váltak azok a nagy volumenü tranzakciók, amelyek során az energiapiac több szegmensében is müködő regionális vállalatcsoportok értékesítésére került sor.

Az elmúlt években az elemzésbe bevont energiaszolgáltatók szinte mindegyike viszszavonult Kelet-Európából, mert a gazdasági feltételek általános romlásán felül e piac gyors liberalizálásával kapcsolatos elvárásaik sem teljesültek. Az első jelentős vállalateladás az E.On nevéhez füződik: a vállalatcsoport 2012-ben eladta a bolgár energiapiac közel egyharmadát ellátó leányvállalatát. 2014-ben a Vattenfall értékesítette a negyedik legnagyobb lengyel energiavállalatban lévő részesedését. Az Enelnek 2015ben sikerült vásárlót találni a legnagyobb szlovák energiavállalatban, a Slovenské Elektrárnében lévő többségi részesedésére. ${ }^{19}$

2010 és 2015 között tözsdei vállalatértékesítésre - a szektor romló eredményessége és a befektetők érdektelensége miatt - alig került sor. A regionális nagyvállalatok eladása elsősorban pályázati kiírás útján történt. Erre példaként említhető az E.On két tranzakciója, amelyeknek során a spanyol és a portugál, illetve az olasz leányvállalataitól vált meg. Az RWE 2015-ben visszavonult a luxemburgi energiapiacról, és szintén pályázati kiírás útján értékesítette az ottani integrált energiavállalatban lévő részesedését. ${ }^{20}$

Az egyetlen klasszikus, magán- és intézményi befektetőket egyaránt érintő eladási tranzakció a portugál EdP privatizálását lezáró lépés volt 2011-ben. Ezt követően 2013-ban és 2014-ben az olasz Enelnek is sikerült a tőzsdén keresztül értékesítenie egy hazai földgázelosztó hálózatban meglévő maradék tulajdoni részesedését, valamint spanyol integrált energiavállalata, az Endesa egyötödét. Az utóbbi tranzakciók azonban kisebb volumenüek voltak, és az új tulajdonosok is csak a befektetők egy szükebb köréből, az intézményi befektetőkből kerültek ki.

A vállalatértékesítés során alkalmazott eljárás típusában 2016-ban következett be fordulat, amikor több, nagy értékű tőzsdei tranzakció is sikeresen lezáródott. Két vállalateladás a zöldenergiához és így a szabályozott energiapiaci szegmenshez kapcsolódott: júniusban a dán állam Európa legnagyobb szélerőmü-kapacitását müködtető cégének, a Dong Energynek az 50 százalékát privatizálta.

2016 végén pedig az E.On és az RWE vitte tőzsdére új, teljes vállalati átszervezés során létrehozott leányvállalatait. A leválasztott új egységek eltérő stratégia alapján szerveződtek. Az RWE a szabályozott piaci tevékenységeket, az elosztóhálózatot és a megújuló energiát hasznosító kapacitásokat választotta le, és az új vállalat (Innogy) közel egynegyedét értékesítette. Az E.On ezzel szemben az alacsonyabb

\footnotetext{
${ }^{19}$ A tranzakciót megnehezítette, hogy a kisebbségi tulajdonos, a szlovák kormány hozzájárulására is szükség volt az új tulajdonos kiválasztásában. A Slovenské Elektrárne tulajdonában vannak a szlovák nukleáris erőmüvek is, amelyek közül a mohovcei teljes modernizálás alatt áll. Ezt a beruházást még a régi tulajdonos, az Enel finanszírozza. A szerződés aláírását követően az Enel a vállalati részesedésének csak felét ruházta át az új tulajdonosra, teljes kilépésére csak az atomerőmüben folyó beruházás befejezését követően kerül sor.

${ }^{20}$ A luxemburgi integrált energiavállalatban meglévő RWE-érdekeltséget pénzügyi alapok és a Luxemburgi Nagyhercegség vásárolta meg.
} 
nyereségességű tevékenységeket, az atomerőművek kivételével az összes hő- és vízi erőművi kapacitását, a kereskedőházát és az orosz részesedését szervezte ki egy új vállalatba (Uniper), és ennek valamivel több mint felét a tőzsdén keresztül eladta. Bár mindkét tranzakció sikeresen befejeződött, a várakozásnak megfelelöen jóval nagyobb volt a befektetői érdeklődés a szabályozott piaci szegmensben müködő, megújuló energiát hasznosító vállalat (Innogy) iránt.

\section{A tulajdonosi szerkezet változása, új tulajdonosok megjelenése az európai energiaszolgáltató szektorban}

A 2010 és 2016 közötti vagyoneladási hullám az energiaszolgáltató szektor decentralizációjával, új tulajdonosok megjelenésével járt. Az átrendeződés során a regionális és központi kormányzatok szerepe kisebb mértékben, a pénzügyi befektetők súlya jelentősen megnövekedett. A szakmai befektetők köre pedig új, gyakran Európán kívüli szereplőkkel bővült. E periódus egyik sajátossága, hogy míg 1998 és 2009 között az új tulajdonosok erős pozíciókat biztosító tulajdoni részesedések megszerzésére és az irányítás átvételére, a vásárolt vagyonnak a meglévő üzleti portfólióba való szoros betagolására törekedtek, az elmúlt években megszerzett tulajdonok kisebb értékủek voltak, és a befektetések nagy része a pénzügyi befektetések jellegzetességeit mutatta.

\section{Regionális energiaszolgáltatók és helyi kormányzatok}

A nagy integrált energiaszolgáltatók gazdasági meggyengülése felerősítette a kisebb regionális szolgáltatók azon törekvését, hogy piaci pozícióikat a domináns szolgáltatók rovására megerősítsék, és azoktól a gyakran közösen működtetett kapacitásokat saját tulajdonba vegyék át. Különösen érezhető volt ez a törekvés a 2008-as válságot követő években, amikor a szektorban bekövetkezett visszaesés még rövid távú, konjunkturális jellegünek látszott.

A sokszereplős német energiapiacon a kommunális szolgáltatók beruházásaik és akvizícióik koordinálására regionális érdekcsoportokba tömörültek. ${ }^{21} \mathrm{~A}$ regionális politika támogatásával egy kisebb decentralizációs hullám is kialakult: az E.On egyik nagy földgázelosztó leányvállalatát (Thüga), valamint az ötödik legnagyobb villamosenergia-kapacitással rendelkező vállalatot (Evonik Steag) egy-egy helyi szolgáltatókból álló konzorcium vásárolta meg.

A helyi szolgáltatók tulajdonosai, a regionális kormányzatok általában támogatták vállalataikat az eladásra szánt helyi közművek, hálózati tevékenységek (villamos energia, földgáz, távfütés, vízellátás) átvételében. A regionális kormányzatokat

${ }^{21}$ 2010-ben a német kommunális energiaszolgáltatók villamosenergia-termelése a szükséglet valamivel több, mint 10 százalékát fedezte. A helyi energiaszolgáltatók érdekképviseletei egy 15 éves periódusban ezt az arányt 25 százalékra kívánták emelni. 
ebben a szolgáltatóktól kapott, relatíve stabil osztalék és adóbevétel motiválta, e jövedelmek - az energiaszektor romló jövedelemtermelő képessége ellenére - a helyi költségvetés legfontosabb bevételi forrásai maradtak. Ezenfelül az energiaszektorban meglévő közvetlen tulajdon lehetőséget ad arra is, hogy a kormányzatok könynyebben megvalósíthassák helyi gazdasági, foglalkoztatási, infrastrukturális céljaikat. Bizonyos esetekben pedig saját maguk vették át és müködtetik a közműveket.

\section{Központi kormányzatok}

Míg a vizsgált időszak első részében az energiaszolgáltató szektorban meglévő állami tulajdon - mindenekelőtt a dél-európai (olasz, spanyol és portugál) vállalatok privatizációja révén - csökkent, a szektor válságának elmélyülésével ellentétes folyamat bontakozott ki. A központi kormányok nemegyszer közvetlen érdekeltségeik révén stratégiailag fontosnak ítélt, eladásra meghirdetett vagyoni elemeket vettek át a pénzügyi nehézségekkel küzdő energiaszolgáltatóktól. ${ }^{22}$

\section{Pénzügyi befektetők}

Az elmúlt években az általános pénzügyi befektetők és az infrastrukturális befektetésekre specializálódott alapok figyelme elsősorban két üzleti tevékenységre és az ezekhez kapcsolódó vagyoni elemekre irányult: az egyik a szabályozott feltételek között müködő hálózati közszolgáltatás és a zöldenergia felhasználásán alapuló energiatermelés, a másik pedig a hosszú távú szerződésekkel fedezett nemzetközi és regionális földgáz-infrastruktúra. E befektetések értéküket viszonylag stabilan megörizték, és a müködési kockázataik is jól behatárolhatók.

Az elmúlt években az európai pénzügyi befektetők, infrastrukturális alapok, biztosítók, nyugdíjalapok széles köre vett részt az energiaszolgáltatás új tulajdonosi szerkezetének kialakításában. Az Európán kívüli pénzügyi befektetők közül két infrastrukturális alap növelte érezhetően jelenlétét: az ausztrál Macquarie és a kanadai Borealis Infrastructure, továbbá kínai pénzügyi befektetők, amelyeket külön pontban tárgyalunk a későbbiekben. ${ }^{23} \mathrm{~A}$ Macquarie az orosz földgáztranzit útvonalán fekvő német és cseh földgázhálózatban, valamint egy német tengeri szélerőmü- és egy olasz vízierőmü-parkban is szerzett részesedést. A kanadai Borealis a finn és a svéd magasfeszültségü villamosenergia-elosztó hálózatokban és a cseh földgázvezetéket müködtető vállalatban vásárolt meghatározó részesedést.

${ }^{22}$ A finn állam vásárolta meg a Fortumtól a finn földgázhálózatban, a Gasumban lévő részesedését. Mivel előzőleg a Gazpromot is kivásárolták, ezzel a lépéssel a földgázhálózatot visszaállamosították. Luxemburg - egy pénzügyi alappal közösen - vette át az RWE-nek a luxemburgi integrált szolgáltatóban, az Enovosban meglévő érdekeltségét.

${ }^{23}$ A Macquarie Group az energiaszektorra és az infrastrukturális befektetésekre szakosodott ausztrál befektetői csoport. A Borealis Infrastructure Management kanadai nyugdíjbiztosító társaság, az Ontario Municipal Employees Retirement System (OMERS) infrastrukturális befektetési alapja. 
A szabályozott piac egyes szegmenseiben akár rövid távon is számolni lehet növekvő értékesítési árakkal, mivel a piacra lépő új befektetők hajlandók megfizetni a vagyonelemek megbecsülhető értékén felül - gyakran jelentős - belépési felárát is. A befektetések relatíve rövid időn belüli újraeladása réven a Macquarie pénzügyi csoport nem publikált, de valószínűsíthetően jelentős árkülönbözetre tehetett szert, amikor 2016-ban továbbértékesítette dél-európai energiakapacitásait, amelyeket korábban a Thyssengastól (német földgázhálózati rendszerüzemeltetőtől) és az E.On-tól vásárolt meg.

\section{Szakmai befektetók}

Az új tulajdonosok közül két aktív szakmai befektetői csoportot fontos megemlíteni: a kínai beruházókat és a cseh Energetický a Průmyslový Holding magánvállalatot. A cseh vállalat az elmúlt öt évben a közép-európai energiaszektor egyik fontos szereplőjévé vált.

\section{Kínai tökebefektetések az európai energiaszolgáltató szektorban}

Az energiaszolgáltató szektorba áramló kínai beruházások 2010 után robbanásszerüen növekedtek. 2016 végéig az Európába áramló összes kínai befektetés közel egyharmada e szektorban koncentrálódott. A befektetések háromnegyede mögött állami vagy vegyes tulajdonú vállalatok és befektetési alapok álltak. ${ }^{24}$

A vizsgált periódus első éveiben a dél-európai régió került a kínai érdeklődés középpontjába. Portugáliában és Spanyolországban a költségvetési hiány mérséklése és az eladósodottság csökkentése érdekében ekkor privatizálták az energiaszolgáltató szektort. A kedvező vételáron felül az új tulajdonosokkal szembeni követelmény volt, hogy a szektor további fejlesztéséhez szükséges új beruházásokat is finanszírozzák.

Az első jelentős kínai befektetés a portugál vertikális energiaszolgáltató, az EdP 2011-es tőzsdei privatizációjához füződik. ${ }^{25}$ Ekkor vált két állami vállalkozás, a China Three Gorges Co. (CTG) ${ }^{26}$ és a China National Investment Co. (CNIC) az EdP közel egynegyedének tulajdonosává. A vételár 2,7 milliárd euró volt, továbbá az új tulajdonosok vállalták, hogy összesen 2 milliárd euró értékben részesedést szereznek a cég néhány érdekeltségében is. Ennek eredményeként a kínai tulajdonosok a portugál vállalat nemzetközi szélerőmüvi parkjában szereztek többségi részesedést.

${ }^{24}$ A kínai beruházások alakulásának 2010 és 2016 közötti bemutatásához az EY [2017] és a Hanemann-Huotari [2017] tanulmányokra támaszkodtunk.

${ }^{25}$ E privatizáció során két arab befektetői csoport, az osztrák OMV szaudi tulajdonosa, az International Petroleum Investment Co. (IPIC) és a Qatar Investment Holding is kisebb részesedésekhez jutott.

${ }^{26}$ A China Three Gorges Co. Kína legnagyobb állami tulajdonban lévő energiaszolgáltatója. E vállalatcsoporthoz tartozik a Jangce folyón épített Három-szurdok vízi erőmủ is. 
E sikeres tranzakciót követően továbbra is e régió maradt a kínai befektetők célpontja. 2012 elején a State Grid Corporation of China (SGCC) közel 600 millió euróért megvásárolta a portugál magasfeszültségü távvezetéket müködtető Redes Energéticas Nacionais (REN) egynegyedét. Ez a tranzakció is egy hosszú távú együttmüködés részét képezte. A kínai fél vállalta, hogy összesen 2,6 milliárd euró értékben finanszírozási forrást nyújt a portugál szolgáltató további beruházásaihoz.

Spanyolország és Kína 2012-ben a megújuló energia hasznosításáról államközi megállapodást írt alá. Ennek révén több spanyol cég épített szélerőmüvi parkokat Kínában. Az együttmüködés kölcsönös előnyöket biztosított, egyrészt a spanyol cégek beléptek egy hatalmas felvevőpiacra, másrészt a kínaiak technológiai know-how-t szereztek egy számukra akkor még újnak számító területen.

2014-ben egy olasz-kínai államközi megegyezés alapján a kínai nemzeti bank, a People's Bank of China (PBOC) 2 százalékos részesedést szerzett az olasz integrált energiakonszernben, az Enelben, amelyért 825 millió eurót fizetett. ${ }^{27} \mathrm{Az}$ Enel új résztulajdonosával együttműködési megállapodást kötött az okos (smart) technológia területére vonatkozóan.

2014-ben az SGCC egyik leányvállalata, a China’s State Grid International Development Ltd. (SGID) szerzett 35 százalékos részesedést az olasz energiahálózatokat összefogó holdingban, a CDP Retiben 2 milliárd euróért. A kínai cég e vásárláson keresztül 35-35 százalékos közvetett tulajdonhoz jutott a földgáz-tranzitvezetéket és a magasfeszültségü elektromos hálózatot működtető, tőzsdén jegyzett két olasz cégben, a Snamban és a Ternában.

Az említett együttműködési megállapodások mindegyike kitért arra, hogy kínai partnerek az európai cégek kínai piaci belépését közös vállalatok létesítése útján segítik, és ezek működéséhez a kínai bankok hitelt is nyújtanak.

2016 októberében a kínai befektetőknek egy újabb regionális energiapiacra sikerült belépniük. A görög magasfeszültségű elektromos hálózatot birtokló állami vállalat, az ADMIE 24 százalékára kiírt pályázatot a legmagasabb, 320 millió eurós ajánlatával a kínai villamosenergia-hálózatot müködtető holding egyik leányvállalata nyerte meg, maga mögé utasítva a pályázó olasz és francia energiaszolgáltatókat.

Mivel közvetlen tőkebefektetéseik révén több dél-európai energiaszolgáltató is aktív Latin-Amerikában, a tulajdoni részesedések és az együttmüködési megállapodások révén a kínai beruházók az általuk kevéssé ismert dél-amerikai régióban is megjelenhetnek. A kínai részvétel a tulajdonszerzés mellett gyakran kiterjed a megújuló energiára, a nap- és szélenergiát hasznosító beruházásokban való közvetlen részvételre is.

Az Egyesült Királyság is a kínai befektetők fontos célországává vált. Az első nagyobb befektetés a vízszolgáltató Thames Water Utility 9 százalékának 2012-es megvásárlása volt. ${ }^{28} \mathrm{Az}$ új résztulajdonos a China Investment Co. (CIC) lett. 2016-ban

\footnotetext{
${ }^{27}$ E megállapodás keretében a kínai állami vagy az államközeli befektetők 2 százalékos részesedést szereztek az állami tulajdonban lévő olasz kőolaj- és földgázkonszernben, az ENI-ben, valamint egy energetikai berendezéseket gyártó vállalatban is.

${ }^{28}$ A vízközmű eredetileg a német RWE egyik befektetése volt. Az RWE tulajdonrészét 2006-ban egy nemzetközi infrastrukturális befektetési alapnak adta el. Ez a csoport értékesítette érdekeltségét 2012-ben a kínai beruházónak.
} 
ez az állami befektetési alap - más pénzügyi befektetőkkel együtt - megvásárolta a brit National Grid földgázelosztó leányvállalatának 61 százalékát.

Kína a következő évtizedekben több mint 120 nukleáris erőmü építését tervezi, ezért az európai atomerőmüvi berendezéseket gyártó cégekkel - ezen belül is elsősorban a francia vállalatokkal - való együttműködése fontossá vált. Az első e területen elért sikerként értékelhető a francia EdF-fel 2016-ban kötött megállapodás, amely a dél-angliai Hinkley Point két új atomenergia-blokkjának közös megvalósítására vonatkozik. A jelenlegi becslések szerinti, közel 20 milliárd eurós projektben, amelynek finanszírozását is a közremüködő vállalatoknak kell biztosítaniuk, a China General Nuclear Power (CGN) 33 százalékos részesedéssel rendelkezik. A kooperáció kölcsönös elönyökön alapul. A piacszerzésen felül a kínai fél betekinthet a francia atomerőmüvi technológiába, az EdF pedig megvalósíthat egy fontos európai projektet, amelynek a beruházási igényét a kedvezőtlen gazdasági feltételek és más vállalt beruházási kötelezettsége mellett egyedül nem lenne képes finanszírozni. Az EdF tárgyalási pozíciói javulhatnak a kínai atomerőmüvek építésére kiírt tendereken is. A felek a későbbiekben közös beruházási alapot kívánnak létrehozni a tervezett afrikai és ázsiai energiapiaci terjeszkedésük finanszírozására.

A kínai beruházóknak a másik nagy francia energiacéget is sikerült megnyerniük. 2015-ben az Engie és a CIC együttmüködési megállapodást írt alá nagy - ezen belül is elsősorban a fejlődő országokban folyó - megújulóenergia-projektekben való közös részvételről. Továbbá a CIC a francia partner kőolaj- és földgázmezőinek fejlesztésében is közreműködik.

Míg Dél-Európában az energiaszolgáltató nagyvállalatokban való közvetlen kínai tulajdonszerzés volt túlsúlyban, Németországban és a skandináv országokban dinamikusan növekedtek a zöldenergiához kapcsolódó közvetlen kínai beruházások (Taylor Wessing [2013]). E részpiacon már a magántőke is megjelent, és egyfajta munkamegosztás alakult ki: a kínai állami cégek a nagyobb, nap- és szélenergiát hasznosító erőművek átvételében érdekeltek, a magánvállalatok figyelme ezzel szemben az erőmüvi berendezések gyártói felé irányul. ${ }^{29}$

Németországban 2011 és 2013 között a megújuló energián alapuló kapacitások közül a gyorsan üzembe helyezhető napenergia-kapacitások nőttek erőteljesen. Ezzel párhuzamosan számtalan napelemet előállító vagy e technológia továbbfejlesztésére szakosodott kis- és középvállalkozás jött létre. A termelöcégek nagy része azonban hamarosan tönkrement, mivel az olcsó kínai napelemmel szemben nem voltak versenyképesek. Az így bajba jutott vállalkozások egy részét kínai, zömében magáncégek vásárolták meg. Az átvett vállalkozásokban a piac ismereténél azonban jóval nagyobb értéket képviselnek a cégek technológiai fejlesztései, amelyek gyakran szabadalmi védettség alatt is állnak.

\footnotetext{
${ }^{29} 2016$ nyarán a CTG nyújtotta be a legmagasabb ajánlatot az Északi-tengeren létesített egyik legnagyobb német offshore szélerőműpark, a Meerwind 80 százalékos részesedéséért, maga mögé utasítva több európai pénzügyi befektetőt. Az eladó - egy amerikai befektetési alap - 2014-ben vásárolta meg a szélerőmüparkot.
} 
2016 a német energiapiacon a kínai befektetők éve volt. Az év elején a többségi állami tulajdonban álló Beijing Enterprises Holdings Ltd. kereken 1,5 milliárd eurót fizetett egy vállalatcsoportért, amely a háztartási hulladék feldolgozása révén energiát állít elö (waste-to-energy). ${ }^{30}$ Németországban ez az eddigi legnagyobb kínai befektetés. A hulladékhasznosító eredetileg az E.On leányvállalataként működött, ezt követően egy pénzügyi befektetőhöz került, ami a piacon elöször megjelenő kínai vásárlónak adta el a részesedését.

Kínában is gyorsan nő a megújuló energia szerepe, és a vállalatok erős pozíciókat építettek az ennek hátterét adó, energetikai berendezéseket gyártó ágazatokban is. A szélerőmüvi turbinák 14 legnagyobb gyártója közül 8 kínai. ${ }^{31}$ A kínai cégek közül több is rendelkezik részesedéssel kisebb német és holland turbinagyártó vállalkozásokban, és fejlődésükben fontos szerep jutott az európai befektetéseknek. A 2016-os rangsor alapján (Handelsblatt [2016]) a legnagyobb turbinagyártó, a kínai Goldwind 2008-ban szerzett 70 százalékos tulajdont egy német erőművi technológiával foglalkozó cégben. Ennek szabadalmaztatott technológiáját alkalmazva rendkívül gyors fejlődési utat járt be, és ma már szinte minden kontinensen saját gyártóbázissal is rendelkezik.

2016 másik fontos kínai magánberuházása is az egyik legnagyobb turbinagyártóhoz füződik. Az Envision - több befektetővel együtt - jelentős tőkeemelést hajtott végre egy villamosenergia-raktározással foglalkozó német vállalkozásban. Európai pozíciói kiépítésére az Envision összesen 1 milliárd eurós beruházásra vagy tulajdonrész vásárlására készül.

A kínai befektetőknek a technológiaintenzív kulcsszektorokban bekövetkezett agresszív terjeszkedése növekvő aggodalmat vált ki. ${ }^{32}$ A hagyományos európai energiaszolgáltatók az utóbbi években meggyengültek, az ágazati beruházások gyakran a termelöberendezések állagfenntartásához szükséges szintre csökkentek. A kényszerüen végrehajtott vagyoneladásoknál is egyre szükül a szakmai befektetők köre. A kínai beruházók nemcsak vonzó vételárat ajánlanak az európai energiaszolgáltatóknak, hanem együttmüködést is, azaz a nagy ázsiai piacokra való bejutás megkönnyítését, új beruházások finanszírozását vagy éppen a meglévő hitelek kiváltását. Ezek a gazdasági feltételek az európai energiapiacról jelenleg hiányoznak.

${ }^{30}$ Az EEW Energy from Waste GmbH. kiterjedt hálózattal rendelkezik, 18 üzemet működtet Németországban.

${ }^{31}$ A kínai vállalatokon kívül négy német, egy amerikai és egy dán cég szerepel e listán. A speciális technológiára épülő turbinagyártásban napjainkban igen erős piaci koncentráció zajlik: 2016ban a német cégek pozíciói a francia és spanyol versenytársak felvásárlása révén megerősödtek (Handelsblatt [2016]).

${ }^{32}$ A termelőkapacitások vagy vállalatok értékesítése során a gyakran indokolatlanul magas kínai árajánlatokkal az európai pályázók nem tudnak versenyezni. Ezt a helyzetet súlyosbítja az is, hogy a WTO és Kína közötti szerződés alapján 2017-től Kínát piacgazdaságnak kell tekinteni, így a kínai árukkal szemben az eddigi piacvédő eszközök, például átmeneti vámok dömpingárnak ítélt árak esetén sem alkalmazhatók. A kínai tőkebefektetések várható alakulásával foglalkozik a $P W C$ [2017] elemzése. 


\section{Az energiapiaci trendekkel szemben - Energetický a Průmyslový Holding}

Az energiapiac szakmai befektetői között egy cseh befektetési csoport, az Energetický a Průmyslový Holding (EPH) egyedi fejlődési utat járt be. A vállalatot 2009-ben alapították olyan magánszemélyek, akik korábban nem rendelkeztek energiaipari tapasztalatokkal. A vállalkozás az elmúlt öt évben építette ki az energiaportfólióját. ${ }^{33}$

A társaság első befektetéseit a cseh piacon müködő, kisebb távhőszolgáltató cégek jelentették. Ezt több beruházás követte az európai földgáztranzit útvonalán kulcsfontosságú cseh és szlovák földgázvezetéket és földgáztározókat működtető vállalkozásokban. Az e vállalatokban megszerzett részesedések ugyan nem haladják meg a 49 százalékot, azonban a szerződések szerint a kisebbségi részesedéseket mindenütt kiegészíti a a cégek feletti teljes irányítási jog is, így a befektetői csoport meghatározó a vállalatok operatív müködésében és stratégiájuk kialakításában.

Az EPH markáns, a jelenlegi energiapiaci trendekkel ellentétes stratégiát követ. A zöldenergia növekedésének és a nukleáris erőművek bezárásának energiaellátási kockázatát elörevetítve, hagyományos erőmüvi kapacitásokat vásárol, és ezek reneszánszára számít. Így nem véletlenül került érdeklődésük középpontjába a német energiapiac, ahol az átalakulás folyamata rendkívül gyors, az új erőmüvi kapacitások és az ezeket az ország energetikai rendszeréhez kapcsoló új távvezetékek kiépítése nincs egymással összhangban. Mindez növeli a 2022 utáni energiaellátással kapcsolatos kockázatokat. ${ }^{34} \mathrm{Az}$ EPH 2011-ben megvásárolta a cseh CEZ és az E.On szénbázisú hőerőmüveit és az ezeket kiszolgáló barnaszénbányákat. Ezt a portfóliót egészítették ki 2016-ban a Vattenfalltól átvett, barnaszénen alapuló kapacitásokkal.

Az EPH 2015-ben megvásárolta az olasz Enelnek a Slovenksé Elektrarnében meglévő kétharmados tulajdonrészét. Ez a vásárlás az EPH-t hosszú távon is a közép-európai energiapiac egyik fontos szereplöjévé tette. Ebben a portfólióban található ugyanis a teljes modernizálás alatt álló mohovcei atomerőmü is, amelynek beruházási költségeit még az eladója, az Enel állja. Ugyanebben az évben vették át a közép-európai piacról visszavonuló francia EdF Budapesti Erőmü Zrt.ben lévő 95,6 százalékos részesedését.

Az EPH a közvetlen regionális piacán kívül is erőteljesen terjeszkedik. Az utóbbi két évben két kisebb angol hőerőmüvet, valamint délolasz villamosenergia-kapacitásokat is megvásárolt. Az EPH vásárlásainak teljes összegéről nincs képünk, mivel a vételárat csak az akvizíciók egy részében hozták nyilvánosságra. Az EPH ismert összes beruházási kiadása azonban az elmúlt öt évben jóval meghaladta a 4 milliárd

\footnotetext{
${ }^{33}$ Az EPH-t néhány cseh magánszemély alapította. A vállalkozás élén 94 százalékos tulajdoni aránynyal a jogi végzettségü, az alapításkor még csak 34 éves Daniel Kretinsky áll, akihez a csoport befektetési stratégiájának kialakítása is füződik. Kretinsky számtalan egyéb területen is aktív: elnöke a Sparta Praha futballcsapatának, 2013-ban pedig megvásárolt egy cseh lapkiadói csoportot az Axel Springer és Ringier lapkiadó konzorciumtól.

${ }^{34}$ A megújuló energián alapuló termelőkapacitások bővülése mögött a vezetékhálózat kiépítése többéves lemaradásban van. Ezért több új kapacitás nem kapcsolható be a központi energiahálózatba. Különösen jelentős a lemaradás az észak-déli magasfeszültségű villamosenergia-hálózat építésében. $\mathrm{Az}$ atomerőművek 2022-es teljes leállítását követően ezen az úton jutna el a tengeri szélerőművek által termelt áram a délnémet fogyasztókhoz.
} 
eurót. ${ }^{35} \mathrm{~A}$ finanszírozáshoz szükséges források kisebb részét az EPH stabilan müködő földgáz- és távhőszolgáltató-portfóliója biztosítja, a tulajdonvásárlás nagyobb része azonban bankhitelből történik.

Az EPH 2015-ben átstrukturálta részesedéseit. A zömében hosszú távú szerződésekkel fedezett vagy szabályozott gazdasági környezetben müködő vállalkozásokat, így az európai földgáztranzitban részt vevő vállalatokat, a cseh és szlovák villamosenergia-hálózatot, valamint a távhőszolgáltatókat egy új holdingba - EP Infrastructure Holding (EPIH) - fogták össze. Ez a 87 százalékban szlovák, 13 százalékban cseh vállalatokból álló csoport rendelkezik az európai földgáztranzitút mentén rendelkezésre álló földgáztároló kapacitások 25 százalékával. Ezt egészíti ki a működés feletti ellenőrzés joga a szlovák földgázvezetékben, több cseh és szlovák villamosenergia- és földgázelosztó hálózatban. ${ }^{36} \mathrm{Az} \mathrm{EPH}$ továbbra is bővíteni kívánja közép-európai földgázportfólióját. ${ }^{37}$

Az EPH 2016 tavaszán elindította a stabil árbevételt és nyereséget biztosító leányvállalatának, az EPIH-nek az értékesítését. E vállalatcsoport összértékét 5,0-7,6 milliárd euróra becsülték. A tulajdonos a részvények 15-30 százalékát kívánta tőzsdére vinni. Az elözetes piackutatás tapasztalatai alapján azonban elálltak e tranzakciótól. Ennek fő oka az volt, hogy potenciális befektetők nem értettek egyet az eladásból származó bevétel tervezett felhasználásával. Ezt ugyanis nem a holding további terjeszkedésére fordították volna, hanem az EPH passzív pénzügyi befektetőinek kivásárlására, amivel a stratégiát meghatározó tulajdonos pozíciója is tovább erősödött volna. ${ }^{38}$

\section{Új regionális akvizíciós irány}

Az elmúlt években az európai energiaszolgáltató piacon regionális irányváltás is történt. Az előző évtizedben a dél-európai cégek elsősorban mint befektetési célpontok jöttek számításba, idővel azonban néhány hálózatot müködtető, stabil jövedelmezőségü dél-európai cég befektetőként jelent meg és szerzett az észak- és nyugat-európai piacokon érdekeltségeket. Két sikeresen fejlődő, földgázhálózati rendszereket üzemeltető vállalat, az olasz Snam és a spanyol Enagas vállalatfelvásárlásai és befektetési portfóliójának alakulása érdemel figyelmet.

Az olasz Snam Európa egyik legnagyobb földgáz-tranzithálózatát és -tárolóit müködtető vállalata. A vállalatcsoport stratégiai célja az európai tranzitút mindkét

${ }^{35}$ A délolasz erőművek és a szlovák szolgáltató kétharmadának vételi ára összesen 1,5 milliárd eurót tett ki.

${ }^{36}$ A holding 2015-ben 3,4 milliárd eurós árbevételt és több mint 1,4 milliárd euró értékcsökkenési leírás előtti operatív nyereséget ért el. Az EPH hőerőművi kapacitásai szervezetileg e holdingtól függetlenek, és az EPH közvetlen irányítása alatt állnak.

${ }^{37}$ 2016-ban ajánlatot tettek az osztrák OMV földgázkereskedő leányvállalatának, a Gas Connect Austriának a 49 százalékára.

${ }^{38}$ A befektetői szerkezet átalakítása más módon valósult meg: a nyilvános értékesítés helyett 2016 októberében egy nemzetközi befektetői konzorcium megvásárolta az EPIH 30 százalékát. Ezt követően a passzív pénzügyi befektetők kivásárlása is megtörtént. Jelenleg a teljes vállalatbirodalmat átfogó holding 94 százaléka egyetlen tulajdonos kezében összpontosul. 
irányú, a keletről nyugatra és a délről északra tartó útvonalába való aktív bekapcsolódás. Ezt az expanziót szolgálta a Nagy-Britanniát Európával összekötö, tenger alatti földgázvezeték, az Interconnector résztulajdonának megszerzése. ${ }^{39}$ Ezenfelül a Snam bevásárolta magát a francia földgázhálózatba, TIGF-be is, amely a délfrancia és az északspanyol fogyasztókat szolgálja ki, valamint több, cseppfolyósított földgáz átvételére és tárolására alkalmas kikötői kapacitást kapcsol be az európai földgázhálózatba. A Snam részt vesz a tervezett adriai gázvezeték (Trans Adriatic Pipeline, TAP) létesítésében is. Ez a vezeték a Közép-Ázsiából származó földgázt Görögországon, Albánián és az Adriai-tengeren át Dél-Olaszországba fogja eljuttatni.

A 2016-os év fontos állomás volt a vállalatcsoport stratégiájának megvalósításában: a Snam ekkor szerzett részesedést a földgáz-nagykereskedő Gas Connect Austriában, és növelte részesedését a kelet-nyugati földgáztranzitút osztrák szakaszát müködtető Trans Adriatic Pipeline-ban is. Az év végén pedig sikeresen tőzsdére vitte a belföldi fölgázelosztásban érdekelt leányvállalatát, az Italgast. A tranzakció bevételei segíteni fogják a Snam stratégiai céljainak megvalósítását.

A spanyol Enagas hasonló irányú, de volumenében jóval kisebb terjeszkedésbe fogott. Részesedést szerzett a svéd földgázhálózatot müködtető Swedegasban és a Trans Adriatic Pipeline-ban. Ezenfelül az Enagas a hazai földgázpiac konszolidációjának egyik aktív résztvevőjévé vált.

\section{További várható eladások az európai energiaszektorban}

A következő években az európai energiaszolgáltató piacon várhatóan folytatódni fog a vagyonelemek, részesedések értékesítése, így a tulajdonosi szerkezet további folyamatos módosulásával számolhatunk.

A még nyitott vagyoneladási programok alapján a két francia energiacsoport, azEdF és az Engie, az olasz Enel és a német EnBW részéről várhatók nagyobb tranzakciók.

$\mathrm{Az}$ EdF az atomerőmüvi biztonságtechnika növekvő terheit, a megvalósulás alatt álló hazai és a kezdés előtt álló angol atomerőmüvek finanszírozási igényeit részben a 2020 -ig tartó 10 milliárd euró célösszegű vagyoneladás révén kívánja finanszírozni. E terv két nagyobb eladást foglal magában: az olasz földgázszállításban fontos szerepet játszó leányvállalat és a lengyel szénbázisú hőerőművi portfólió elidegenítését. Az EdF 2017 májusában egy, a piacon meghatározó lengyel energiaszolgáltatóval megállapodott üzleti pórtófóliójának átadásáról. Az olasz Edison eladását nyilvános kibocsátás formájában tervezi. Az EdF fontolgatja az Egyesült Királyságban működő szén- és földgázbázisú erőművei eladását is. Feszített beruházási tervei miatt nem tudja e kapacitásait modernizálni. Ennek hiányában pedig ezek az erőművek nem fognak megfelelni a szigorodó szén-dioxid-kibocsátási normáknak.

A másik francia cég, az Engie is a lengyel piac teljes elhagyására készül, és elökészíti belga integrált leányvállalatának, az Electrabelnek a tőzsdei értékesítését is.

\footnotetext{
${ }^{39} \mathrm{Ez}$ a 15 százalékos részesedés korábban a német E.On és az olasz ENI tulajdona volt.
} 
A francia energiapiacon a következő években az ismert vagyoneladási programokon felül is számolhatunk az erőmüvi kapacitások értékesítésével. Az EdF és az atomerőmüvi portfólióval rendelkező Areva 2016-os fúzióját követően várható a párhuzamosságok megszüntetése és a közös kapacitáspark egy részének leépítése.

$\mathrm{Az}$ EnBW a hazai hőerőmüvi energiaportfóliójába tartozó több, kisebb vagyonelemének és az új szélerőmüparkok kisebbségi részesedésének eladásával kívánja jövőbeli beruházásait finanszírozni.

Romlottak a német energiapiac egyik szabályozott szegmensének - földgáztranzit, -elosztás és -tárolás - a középtávú profitkilátásai is. A 2017 januárjától érvénybe lépő szabályozás az elözőnél jóval kisebb jövedelmezőségi szint elérését teszi lehetővé. Ezen túlmenően a földgáztárolás jelentőségét az elmúlt években mérsékelte a hatékonyabb energiafelhasználás és az alternatív energiaforrások megjelenése is. Így az ellátás biztonságának mint árképző tényezőnek a súlya csökkent, és a földgáztárolók téli és nyári használati díja közötti különbség is zsugorodott. Az E.On-ból kivált Uniper jelenleg vizsgálja teljes földgáztározói vagyonának az eladhatóságát.

Az erőmüvi kapacitások piacának kínálati oldalán a közeljövőben a svájci energiaszolgáltatók megjelenésével is számolni kell. Az alacsonyabb jövedelmezőség ellensúlyozására az elmúlt években is sor került a villamosenergia-hálózat és a vízierőmü-kapacitás egyes elemeinek az eladására. Nemrégiben az öt atomerőmüvet is üzemeltető svájci energiavállalat bejelentette, hogy meg kíván válni több hő- és vízi erőművétől. A meghirdetett és megvalósítás alatt álló értékesítési programokon felül több energiaszolgáltató is jelezte, hogy a jövedelmezőség tartós csökkenése miatt további vagyonelemek eladását fontolgatja.

\section{Európai energiaszolgáltató szektor - merre tovább?}

Az Európai Unió energiaszolgáltató szektorában az elmúlt közel két évtizedben folyamatos volt a termelőkapacitások tulajdonjogának újraelosztása, a tulajdonosi szerkezet módosulása. A viszonylag hosszú periódus két jól elkülöníthető szakaszra bontható.

Az első, közel tízéves periódusban a villamos energia iránti kereslet gyors növekedése és a tevékenység javuló jövedelmezősége a beruházások és a szektor gyors fejlődését tette lehetővé. Ezt a folyamatot a vállalatfelvásárlások sora kísérte. A fúziók az energiaszolgáltató szektor minden szegmensére kiterjedtek, és túllépték a nemzeti kereteket. Ebben az időszakban az integrált nagyvállalatok az európai energiaszolgáltató szektort egyre inkább saját belső piacuknak és a tartós vállalati növekedés bázisának tekintették. Ezt a folyamatot a szektor liberalizálására irányuló uniós intézkedéscsomag is elősegítette. Bár egyes nemzeti piacokon a liberalizáció üteme és mértéke gyakran elmaradt attól, amit az EU-nak az energiaszolgáltató szektorra vonatkozó első liberalizációs csomagja tartalmazott, a szektor összességében gazdaságosabbá és áttekinthetőbbé vált.

Az elmúlt tíz évben az európai energiaszolgáltató szektort több külső sokk érte. A 2008-as gazdasági válság hatásaként a termelőszektorok villamosenergia-igénye visszaesett, vagy növekedése mérséklődött. Az energiahatékony technológiák 
elterjedésének következtében pedig a villamos energia mennyiségi kereslete tartósan mérséklődött. Az Európai Unió zöldenergia iránti elköteleződése, a megújuló energiát hasznosító kapacitások pénzügyi és egyéb, nem piaci eszközökkel való támogatása alapjaiban alakította át a szektor működési feltételeit.

A hagyományos energiaszolgáltatók lehetöségei az új körülményekhez való gyors és sikeres alkalmazkodásra korlátozottak. A stratégiai váltáshoz, az üzleti portfólió átalakításához új fejlesztésekre, beruházásokra van szükség. A szektor jövedelmezőségének gyengülésével azonban a szolgáltatók hitelfelvevő képessége jelentősen romlott. Ezenfelül a vállalatok zömét még mindig az előző ciklus beruházásainak hitel-visszafizetési kötelezettsége terheli. Az energiaszolgáltató szektor müködési költségei a zöldenergia magas támogatottsága, az erőmüvi biztonságtechnika követelményeinek szigorodása és a nagy volumenủ hálózati fejlesztések következtében emelkedtek. Az elmúlt években a nagy európai energiaszolgáltatók visszavonultak európai piacaikról, megváltak üzleti portfóliójuk jelentős részétől. A vállalati növekedés bázisának a hazai piacot és az Európán kívüli régiókat tekintik. A szektor tulajdonosi köre módosult, növekszik a nem szakmai és az Európán kívüli befektetők aránya.

A következő években a szektorban új konszolidációs hullám várható. A hagyományos energiaszolgáltatók ugyanis szükítik üzleti profiljukat, és az üzleti kockázat csökkentése érdekében a szabályozott piaci szegmensek - zöldenergián alapuló villamosenergia-termelés, hálózatirendszer-üzemeltetés - felé fordulnak. A hagyományos, alacsony jövedelmezőségü, de a villamosenergia-termelésben továbbra is fontos szerepet játszó hőerőművi kapacitások pedig egy-egy nagyobb vállalati egységbe koncentrálódhatnak, és az így nyerhető szinergia révén jövedelmezőségük is javulhat. Az európai energiaszolgáltató szektor tulajdonosi struktúrájának átalakulási folyamata még messze nem záródott le.

\section{Hivatkozások}

EC [2016]: Energy prices and costs in Europe. Report from the Commission to the European Parliament. The European Economic and Social Committee and the Committee of the regions, Comission staff working document, SWD (2016) 420 final, Brüsszel, november 30. http://ec.europa.eu/energy/sites/ener/files/documents/swd2.pdf.

Everts, M.-Blume, H.-Werry-Claus, E. [2016]: Politics vs markets: How German power prices hit the floor. Journal of World Energy Law \& Business, Vol. 9. No. 2. 116-123. o. https://doi.org/10.1093/jwelb/jww005.

EY [2017]: Chinesische Unternehmenskäufe in Europa. Eine Analyse von M\&A-Deals 20062016. EY, http://www.ey.com/Publication/vwLUAssets/ey-chinesische-unternehmenska eufe-in-europa/\$FILE/ey-chinesische-unternehmenskaeufe-in-europa.pdf.

HANDELSBlatT [2016]: Die größten Windkraft-Konzerne der Welt. http://www.handelsblatt. com/unternehmen/industrie/erneuerbare-energien-die-groessten-windkraft-konzerneder-welt/13479906.html\#item8.

Hanemann, T.-HuotaRi, M. [2017]: Record flows and growing imbalances. Chinese Investment in Europe in 2016. Rhodium Group, http://rhg.com/wp-content/uploads/2017/01/ RHG_Merics_COFDI_EU_2016.pdf. 
Hirth, L. [2018]: What caused the drop in European electricity prices? A factor decomposition analyses. The Energy Journal, Vol. 39. No. 1. 143-158. o. https://doi. org/10.5547/01956574.39.1.lhir, korábbi verzió megjelent: Neon Neue Energieökonomick GmbH, Berlin, 2016, https://papers.ssrn.com/sol3/papers.cfm?abstract_id=2874841.

Kallabis, T.-PAPE, C.-Weber, C. [2016]: Investigating the plunge in German electricity futures prices. Strommarktreffen, Berlin, január 22. http://www.strommarkttreffen.org/ 2016-1-22-Kallabis-Investigating-German-electricity-futures-prices.pdf.

Leveque, F.-Monturus, R. [2008]: Mergers \& Acquisitions within the European Power and Gas Sectors. CERNA, Ecole des Mines de Parism Cases and Pattern, Párizs.

PWC [2010]: Mergers and acquisitions activity within the global electricity and gas market. Power Deals, 2009. Annual Review. PriceWaterhouseCoopers.

PWC [2017]: Power \& Renewables Deals 2017: What lies ahead for M\&A? PriceWaterhouseCoopers, PwCGlobal Power \& utilities publications http://www.pwc.com/gx/en/industries/ energy-utilities-mining/power-utilities/publications/power-and-renewables-deals.html.

Taylor Wessing [2013]: Crouching Tiger. How China will impact Europe's renewable energy landscape. Taylor Wessing, https://united-kingdom.taylorwessing.com/documents/get/66/ crouching-tiger-how-china-will-impact-europes-renewable-energy-landscape.pdf. 


\section{Függelék}

F1. táblázat

A tulajdonosi struktúra változásának összefoglaló táblázata

\begin{tabular}{|c|c|c|c|c|c|c|}
\hline $\begin{array}{l}\text { Energia- } \\
\text { szolgáltató cég }\end{array}$ & $\begin{array}{c}\text { Eladási } \\
\text { év }\end{array}$ & $\begin{array}{l}\text { Vagyon } \\
\text { típusa }\end{array}$ & Régió & $\begin{array}{l}\text { Százalékos } \\
\text { részesedés }\end{array}$ & $\begin{array}{l}\text { A vevő } \\
\text { típusa }\end{array}$ & $\begin{array}{c}\text { A vevő } \\
\text { székhelye }\end{array}$ \\
\hline \multicolumn{7}{|l|}{ Erömüvek } \\
\hline \multirow[t]{2}{*}{ E.On (német) } & 2012 & vízi erőmü ${ }^{\star}$ & Németország & 100,0 & $\begin{array}{l}\text { regionális } \\
\text { szolgáltató }\end{array}$ & Ausztria \\
\hline & 2015 & vízi erőmü & Olaszország & 100,0 & $\begin{array}{l}\text { regionális } \\
\text { szolgáltató }\end{array}$ & Olaszország \\
\hline Fortum (finn) & 2012 & vízi erőmü & Finnország & 100,0 & $\begin{array}{l}\text { regionális } \\
\text { szolgáltató }\end{array}$ & Finnország \\
\hline Enel (olasz) & 2015 & $\begin{array}{c}\text { vízi } \\
\text { erőművek }\end{array}$ & Olaszország & 49,0 & Macquarie & Ausztrália \\
\hline \multirow[t]{5}{*}{ E.On (német) } & 2013 & hőerőmü & Németország & 62,8 & $\begin{array}{l}\text { regionális } \\
\text { szolgáltató }\end{array}$ & Németország \\
\hline & $\begin{array}{l}2010 \\
2014\end{array}$ & hőerőmü & Németország & 100,0 & $\begin{array}{c}\text { regionális } \\
\text { szolgáltatók } \\
\text { konzorciuma }\end{array}$ & Németország \\
\hline & 2014 & hőerőmü & Svédország & 100,0 & $\begin{array}{l}\text { regionális } \\
\text { szolgáltató }\end{array}$ & Norvégia \\
\hline & 2015 & hőerőmü & Olaszország & 100,0 & $\mathrm{EPH}^{\star *}$ & $\begin{array}{c}\text { Cseh } \\
\text { Köztársaság }\end{array}$ \\
\hline & 2013 & fütőerőmü & $\begin{array}{c}\text { Cseh } \\
\text { Köztársaság }\end{array}$ & 100,0 & $\begin{array}{l}\text { regionális } \\
\text { kormányzat }\end{array}$ & $\begin{array}{l}\text { Cseh } \\
\text { Köztársaság }\end{array}$ \\
\hline EdF (francia) & 2013 & hőerőmü & $\begin{array}{l}\text { Egyesült } \\
\text { Királyság }\end{array}$ & 100,0 & $\mathrm{EPH}^{\star *}$ & $\begin{array}{c}\text { Cseh } \\
\text { Köztársaság }\end{array}$ \\
\hline RWE (német) & 2016 & hőerőmü & $\begin{array}{l}\text { Egyesült } \\
\text { Királyság }\end{array}$ & 100,0 & $\mathrm{EPH}^{\star *}$ & $\begin{array}{c}\text { Cseh } \\
\text { Köztársaság }\end{array}$ \\
\hline \multirow[t]{4}{*}{ EnBW (német) } & 2011 & hőerőmü & Lengyelország & 32,5 & $\mathrm{EdF}$ & Franciaország \\
\hline & 2011 & fütőerőmü & Lengyelország & 15,6 & $\mathrm{EdF}$ & Franciaország \\
\hline & 2010 & $\begin{array}{c}\text { tengeri } \\
\text { szélerőmu” }\end{array}$ & Németország & 49,9 & $\begin{array}{l}\text { regionális } \\
\text { szolgáltató }\end{array}$ & Németország \\
\hline & 2015 & $\begin{array}{c}\text { tengeri } \\
\text { szélerőmű }\end{array}$ & Németország & 49,9 & Macquarie & Ausztrália \\
\hline $\begin{array}{l}\text { Iberdrola } \\
\text { (spanyol) }\end{array}$ & 2014 & $\begin{array}{l}\text { szárazföldi } \\
\text { szélerőmü }\end{array}$ & Lengyelország & 75,0 & $\begin{array}{l}\text { regionális } \\
\text { szolgáltató }\end{array}$ & Lengyelország \\
\hline EdP (portugál) & 2013 & $\begin{array}{l}\text { szárazföldi } \\
\text { szélerőmü }\end{array}$ & $\begin{array}{l}\text { Olaszország, } \\
\text { Lengyelország }\end{array}$ & $\begin{array}{r}49,0 \\
100,0\end{array}$ & $\begin{array}{c}\text { partner, } \\
\text { szolgáltató } \\
\text { és pénzügyi } \\
\text { befektető }\end{array}$ & nemzetközi \\
\hline Fortum (finn) & 2015 & szélerőmü & Franciaország & 100,0 & $\begin{array}{c}\text { szakmai } \\
\text { befektető }\end{array}$ & Németország \\
\hline
\end{tabular}


Az F1. táblázat folytatása

\begin{tabular}{|c|c|c|c|c|c|c|}
\hline $\begin{array}{l}\text { Energia- } \\
\text { szolgáltató cég }\end{array}$ & $\begin{array}{c}\text { Eladási } \\
\text { év }\end{array}$ & $\begin{array}{l}\text { Vagyon } \\
\text { típusa }\end{array}$ & Régió & $\begin{array}{l}\text { Százalékos } \\
\text { részesedés }\end{array}$ & $\begin{array}{l}\text { A vevó } \\
\text { típusa }\end{array}$ & $\begin{array}{l}\text { A vevő } \\
\text { székhelye }\end{array}$ \\
\hline \multicolumn{7}{|c|}{ Szénhidrogénvagyon, -részesedések } \\
\hline \multirow[t]{3}{*}{ E.On (német) } & 2009 & Gazprom $^{\star * *}$ & Oroszország & 2,9 & Gazprom & Oroszország \\
\hline & 2010 & Gazprom & & 3,5 & bank & Oroszország \\
\hline & 2015 & $\begin{array}{c}\text { tengeri } \\
\text { kőolaj-, } \\
\text { földgázmező }\end{array}$ & $\begin{array}{l}\text { Norvégia, } \\
\text { Egyesült } \\
\text { Királyság }\end{array}$ & 100,0 & $\begin{array}{l}\text { szakmai } \\
\text { befektető }\end{array}$ & $\begin{array}{l}\text { Luxemburg, } \\
\text { Oroszország }\end{array}$ \\
\hline Enel (olasz) & 2013 & $\begin{array}{l}\text { földgáz- } \\
\text { mezök }\end{array}$ & Oroszország & 40,0 & $\begin{array}{c}\text { kőolaj-, } \\
\text { földgázvállalat }\end{array}$ & $\begin{array}{l}\text { Luxemburg, } \\
\text { Oroszország }\end{array}$ \\
\hline Engie (francia) & 2011 & $\begin{array}{c}\text { tengeri } \\
\text { kőolaj-, } \\
\text { földgázmező }\end{array}$ & $\begin{array}{l}\text { Egyesült } \\
\text { Királyság }\end{array}$ & 100,0 & $\begin{array}{l}\text { kőolaj-, földgáz- } \\
\text { vállalat, szakmai } \\
\text { befektető }\end{array}$ & $\begin{array}{l}\text { Francia- } \\
\text { ország, Kína }\end{array}$ \\
\hline \multirow[t]{2}{*}{ RWE (német) } & 2012 & $\begin{array}{c}\text { tengeri } \\
\text { kőolaj-, } \\
\text { földgázmező }\end{array}$ & Norvégia & 20,0 & $\begin{array}{c}\text { kőolaj-, } \\
\text { földgázvállalat }\end{array}$ & Ausztria \\
\hline & 2014 & $\begin{array}{c}\text { tengeri } \\
\text { kőolaj-, } \\
\text { földgázmező }\end{array}$ & $\begin{array}{l}\text { Norvégia, } \\
\text { Egyesült } \\
\text { Királyság }\end{array}$ & 100,0 & $\begin{array}{l}\text { szakmai } \\
\text { befektető }\end{array}$ & $\begin{array}{l}\text { Luxemburg, } \\
\text { Oroszország }\end{array}$ \\
\hline $\begin{array}{l}\text { Vattenfall } \\
\text { (svéd) }\end{array}$ & 2016 & $\begin{array}{l}\text { barnaszén- } \\
\text { bányák }\end{array}$ & Németország & 100,0 & $\mathrm{EPH}^{* *}$ & $\begin{array}{c}\text { Cseh } \\
\text { Köztársaság }\end{array}$ \\
\hline \multicolumn{7}{|c|}{ Földgáz-infrastruktúra } \\
\hline \multirow[t]{9}{*}{ E.On (német) } & 2009 & $\begin{array}{l}\text { elosztó- } \\
\text { hálózat }\end{array}$ & Németország & 100,0 & $\begin{array}{c}\text { regionális } \\
\text { szolgáltatók } \\
\text { konzorciuma }\end{array}$ & Németország \\
\hline & 2010 & távvezeték & $\begin{array}{c}\text { Cseh } \\
\text { Köztársaság }\end{array}$ & 50,0 & $\begin{array}{l}\text { regionális } \\
\text { szolgáltató }\end{array}$ & $\begin{array}{c}\text { Cseh } \\
\text { Köztársaság }\end{array}$ \\
\hline & 2011 & $\begin{array}{l}\text { elosztó- } \\
\text { hálózat }\end{array}$ & Olaszország & 100,0 & $\begin{array}{l}\text { pénzügyi } \\
\text { befektetők }\end{array}$ & $\begin{array}{l}\text { regionális, } \\
\text { nemzetközi }\end{array}$ \\
\hline & 2012 & távvezeték & Németország & 100,0 & $\begin{array}{l}\text { pénzügyi } \\
\text { befektetők }\end{array}$ & nemzetközi \\
\hline & & távvezeték & $\begin{array}{l}\text { Belgium- } \\
\text { Egyesült } \\
\text { Királyság }\end{array}$ & 15,1 & $\begin{array}{c}\text { regionális } \\
\text { szolgáltatók } \\
\text { konzorciuma }\end{array}$ & $\begin{array}{l}\text { Olaszország, } \\
\text { Belgium }\end{array}$ \\
\hline & & távvezeték & Szlovákia & 24,5 & $\mathrm{EPH}^{\star *}$ & $\begin{array}{c}\text { Cseh } \\
\text { Köztársaság }\end{array}$ \\
\hline & & távvezeték & Szlovákia & 44,0 & $\mathrm{EPH}^{* *}$ & $\begin{array}{c}\text { Cseh } \\
\text { Köztársaság }\end{array}$ \\
\hline & & tárolás & Magyarország & 100,0 & $\begin{array}{c}\text { Magyar } \\
\text { Villamos Müvek }\end{array}$ & $\begin{array}{l}\text { Magyar- } \\
\text { ország }\end{array}$ \\
\hline & & tárolás & Szlovákia & 49,0 & $\mathrm{EPH}$ & $\begin{array}{c}\text { Cseh } \\
\text { Köztársaság }\end{array}$ \\
\hline
\end{tabular}


Az F1. táblázat folytatása

\begin{tabular}{|c|c|c|c|c|c|c|}
\hline $\begin{array}{l}\text { Energia- } \\
\text { szolgáltató cég }\end{array}$ & $\begin{array}{c}\text { Eladási } \\
\text { év }\end{array}$ & $\begin{array}{l}\text { Vagyon } \\
\text { típusa }\end{array}$ & Régió & $\begin{array}{l}\text { Százalékos } \\
\text { részesedés }\end{array}$ & $\begin{array}{l}\text { A vevő } \\
\text { típusa }\end{array}$ & $\begin{array}{l}\text { A vevő } \\
\text { székhelye }\end{array}$ \\
\hline \multirow[t]{3}{*}{ Engie (francia) } & 2011 & $\begin{array}{l}\text { elosztó- } \\
\text { hálózat }\end{array}$ & Olaszország & 100,0 & $\begin{array}{l}\text { pénzügyi } \\
\text { befektetők }\end{array}$ & nemzetközi \\
\hline & 2012 & távvezeték & Szlovákia & 24,5 & $\mathrm{EPH}^{\star *}$ & $\begin{array}{c}\text { Cseh } \\
\text { Köztársaság }\end{array}$ \\
\hline & 2013 & távvezeték & $\begin{array}{l}\text { Hollandia- } \\
\text { Dánia- } \\
\text { Németország }\end{array}$ & 33,2 & $\begin{array}{l}\text { regionális szolgál- } \\
\text { tatók és pénzügyi } \\
\text { befektetők }\end{array}$ & nemzetközi \\
\hline \multirow[t]{3}{*}{ RWE (német) } & 2011 & távvezeték & Németország & 100,0 & Macquarie & Ausztrália \\
\hline & 2013 & távvezeték & $\begin{array}{c}\text { Cseh } \\
\text { Köztársaság }\end{array}$ & 100,0 & Borealis & Kanada \\
\hline & 2013 & $\begin{array}{l}\text { elosztó- } \\
\text { hálózat }\end{array}$ & $\begin{array}{c}\text { Magyar- } \\
\text { ország }\end{array}$ & 49,8 & $\begin{array}{c}\text { Magyar Villamos } \\
\text { Müvek }\end{array}$ & $\begin{array}{l}\text { Magyar- } \\
\text { ország }\end{array}$ \\
\hline \multirow[t]{2}{*}{ Fortum (finn) } & 2014 & távvezeték & Finnország & 31,0 & központi kormány & Finnország \\
\hline & 2015 & távvezeték & Észtország & 51,4 & $\begin{array}{l}\text { regionális } \\
\text { szolgáltató }\end{array}$ & Észtország \\
\hline EdP (portugál) & 2012 & távvezeték & $\begin{array}{l}\text { Spanyol- } \\
\text { ország }\end{array}$ & 100,0 & $\begin{array}{l}\text { regionális szolgál- } \\
\text { tató és regionális } \\
\text { kormányzat }\end{array}$ & $\begin{array}{l}\text { Spanyol- } \\
\text { ország }\end{array}$ \\
\hline
\end{tabular}

Villamosenergia-hálózat

Fortum (finn) 2014 távvezeték Finnország 100,0 regionális szol- regionális, gáltató, nemzet- nemzetközi közi befektetők és Borealis

\begin{tabular}{|c|c|c|c|c|c|}
\hline 2014 & távvezeték & Norvégia & 100,0 & $\begin{array}{l}\text { regionális } \\
\text { szolgáltató }\end{array}$ & Norvégia \\
\hline 2015 & távvezeték & Svédország & 100,0 & $\begin{array}{c}\text { nemzetközi } \\
\text { befektetők és } \\
\text { Borealis }\end{array}$ & $\begin{array}{l}\text { regionális, } \\
\text { nemzetközi }\end{array}$ \\
\hline
\end{tabular}

\begin{tabular}{|c|c|c|c|c|c|c|}
\hline EdF (francia) & 2016 & távvezeték & $\begin{array}{l}\text { Francia- } \\
\text { ország }\end{array}$ & 49,9 & $\begin{array}{c}\text { bank és biztosító- } \\
\text { intézet }\end{array}$ & $\begin{array}{l}\text { Francia- } \\
\text { ország }\end{array}$ \\
\hline \multicolumn{7}{|c|}{ Regionális energiavállalatok } \\
\hline \multirow[t]{4}{*}{ E.On (német) } & 2012 & $\begin{array}{c}\text { integrált } \\
\text { szolgáltató }\end{array}$ & Bulgária & 67,0 & $\begin{array}{l}\text { regionális } \\
\text { szolgáltató }\end{array}$ & $\begin{array}{c}\text { Cseh } \\
\text { Köztársaság }\end{array}$ \\
\hline & 2014 & $\begin{array}{l}\text { integrált } \\
\text { szolgáltató }\end{array}$ & $\begin{array}{l}\text { Spanyol- } \\
\text { ország, } \\
\text { Portugália }\end{array}$ & 100,0 & Macquarie & Ausztrália \\
\hline & 2015 & $\begin{array}{l}\text { integrált } \\
\text { szolgáltató }\end{array}$ & Olaszország & 100,0 & $\mathrm{EPH}^{\star *}$ & $\begin{array}{c}\text { Cseh } \\
\text { Köztársaság }\end{array}$ \\
\hline & 2016 & $\begin{array}{c}\text { leányvállalat, } \\
\text { integrált } \\
\text { szolgáltató }\end{array}$ & Németország & 46,7 & $\begin{array}{l}\text { pénzügyi és } \\
\text { magánbefektetők }\end{array}$ & nemzetközi \\
\hline
\end{tabular}


Az F1. táblázat folytatása

\begin{tabular}{|c|c|c|c|c|c|c|}
\hline $\begin{array}{l}\text { Energia- } \\
\text { szolgáltató cég }\end{array}$ & $\begin{array}{l}\text { Eladási } \\
\text { év }\end{array}$ & $\begin{array}{l}\text { Vagyon } \\
\text { típusa }\end{array}$ & Régió & $\begin{array}{l}\text { Százalékos } \\
\text { részesedés }\end{array}$ & $\begin{array}{l}\text { A vevő } \\
\text { típusa }\end{array}$ & $\begin{array}{l}\text { A vevő } \\
\text { székhelye }\end{array}$ \\
\hline \multirow[t]{2}{*}{ RWE (német) } & 2015 & $\begin{array}{l}\text { integrált } \\
\text { szolgáltató }\end{array}$ & Luxemburg & 10,0 & $\begin{array}{l}\text { pénzügyi befek- } \\
\text { tető és központi } \\
\text { kormányzat }\end{array}$ & Luxemburg \\
\hline & 20161 & $\begin{array}{l}\text { leányvállalat, } \\
\text { integrált } \\
\text { szolgáltató }\end{array}$ & Németország & 77,0 & $\begin{array}{l}\text { pénzügyi és } \\
\text { magánbefektetők }\end{array}$ & nemzetközi \\
\hline \multirow[t]{2}{*}{ Enel (olasz) } & 2014 & $\begin{array}{l}\text { integrált } \\
\text { szolgáltató }\end{array}$ & $\begin{array}{l}\text { Spanyol- } \\
\text { ország }\end{array}$ & 25,0 & $\begin{array}{l}\text { pénzügyi és } \\
\text { magánbefektetők }\end{array}$ & nemzetközi \\
\hline & 2015 & $\begin{array}{l}\text { integrált } \\
\text { szolgáltató }\end{array}$ & Szlovákia & 66,0 & $\mathrm{EPH}^{\star *}$ & $\begin{array}{c}\text { Cseh } \\
\text { Köztársaság }\end{array}$ \\
\hline \multirow[t]{2}{*}{ EdF (francia) } & 2015 & $\begin{array}{l}\text { integrált } \\
\text { szolgáltató }\end{array}$ & Ausztria & 25,0 & Macquarie & Ausztrália \\
\hline & 2015 & $\begin{array}{l}\text { integrált } \\
\text { szolgáltató }\end{array}$ & Olaszország & 49,0 & $\begin{array}{l}\mathrm{EPH}^{\star *} \text { és } \\
\text { pénzügyi } \\
\text { befektetők }\end{array}$ & $\begin{array}{c}\text { Cseh } \\
\text { Köztársaság, } \\
\text { nemzetközi }\end{array}$ \\
\hline EnBW (német) & 2011 & $\begin{array}{l}\text { integrált } \\
\text { szolgáltató }\end{array}$ & Svájc & 15,1 & $\begin{array}{c}\text { helyi } \\
\text { szolgáltatók }\end{array}$ & Svájc \\
\hline Engie (francia) & 2010 & $\begin{array}{l}\text { integrált } \\
\text { szolgáltató }\end{array}$ & Belgium & 39,0 & $\begin{array}{c}\text { helyi } \\
\text { szolgáltatók }\end{array}$ & Belgium \\
\hline Fortum (finn) & 2016 & hőerőmü & Oroszország & 100,0 & $\begin{array}{l}\text { regionális } \\
\text { szolgáltató }\end{array}$ & Oroszország \\
\hline $\begin{array}{l}\text { Iberdrola } \\
\text { (spanyol) }\end{array}$ & 2014 & $\begin{array}{l}\text { integrált } \\
\text { szolgáltató }\end{array}$ & Portugália & 6,6 & $\begin{array}{l}\text { regionális } \\
\text { szolgáltató }\end{array}$ & Portugália \\
\hline $\begin{array}{l}\text { Vattenfall } \\
\text { (svéd) }\end{array}$ & 2014 & $\begin{array}{l}\text { integrált } \\
\text { szolgáltató }\end{array}$ & Portugália & 100,0 & $\begin{array}{l}\text { regionális } \\
\text { szolgáltató }\end{array}$ & Portugália \\
\hline
\end{tabular}

Privatizáció

Központi kormányzat

\begin{tabular}{|c|c|c|c|c|c|}
\hline 2011 & $\begin{array}{l}\text { integrált } \\
\text { szolgáltató }\end{array}$ & Portugália & 21,4 & $\begin{array}{l}\text { szakmai és pénz- } \\
\text { ügyi befektetők }\end{array}$ & Kína \\
\hline 2012 & $\begin{array}{l}\text { villamos- } \\
\text { energia- } \\
\text { távvezeték }\end{array}$ & Portugália & 25,0 & $\begin{array}{l}\text { szakmai } \\
\text { befektető }\end{array}$ & Kína \\
\hline 2016 & $\begin{array}{l}\text { villamos- } \\
\text { energia- } \\
\text { távvezeték }\end{array}$ & Görögország & 25,0 & $\begin{array}{l}\text { szakmai } \\
\text { befekteto” }\end{array}$ & Kína \\
\hline 2016 & $\begin{array}{l}\text { integrált } \\
\text { szolgáltató }\end{array}$ & Dánia & 50,0 & $\begin{array}{c}\text { pénzügyi és } \\
\text { magánbefektetők }\end{array}$ & nemzetközi \\
\hline
\end{tabular}

\footnotetext{
* Csereügylet, az E.On a Verbund osztrák szolgáltató török energiaportfólióját vette át.

${ }^{* *}$ Energetický a Průmyslový Holding.

*** A Juzsno-Russzkoje földgázmező csereügylete során átvett 25 százalékos résztulajdonát az E.On 2016-ban leválasztott leányvállalata, az Uniper 2017 tavaszán az osztrák OMV-nak értékesítette.
} 